\title{
THE
}

\section{Comparative biogeochemistry-ecosystem-human interactions on dynamic continental margins}

Lisa A. Levin

Kon-Kee Liu

Kay-Christian Emeis

Denise L. Breitburg

James Cloern

See next page for additional authors

Follow this and additional works at: https://digitalcommons.uri.edu/gsofacpubs

This is a pre-publication author manuscript of the final, published article.

Creative Commons License

c) (i) $\Theta$

This work is licensed under a Creative Commons Attribution-Noncommercial-No Derivative Works 4.0 License.

\section{Citation/Publisher Attribution}

Levin, L. A., Liu, K.-K., Emeis, K.-C., Breitburg, D. L., Cloern, J., Deutsch, C., Giani, M.,...Wishner, K. (2015). Comparative biogeochemistry-ecosystem-human interactions on dynamic continental margins. Journal of Marine Systems, 141, 3-17. doi: 10.1016/j.jmarsys.2014.04.016

Available at: https://doi.org/10.1016/j.jmarsys.2014.04.016

This Article is brought to you for free and open access by the Graduate School of Oceanography at DigitalCommons@URI. It has been accepted for inclusion in Graduate School of Oceanography Faculty Publications by an authorized administrator of DigitalCommons@URI. For more information, please contact digitalcommons-group@uri.edu. 


\section{Authors}

Lisa A. Levin, Kon-Kee Liu, Kay-Christian Emeis, Denise L. Breitburg, James Cloern, Curtis Deutsch, Michele Giani, Anne Goffart, Eileen E. Hofmann, Zouhair Lachkar, Karin Limburg, Su-Mei Liu, Enrique Montes, Wajih Naqvi, Olivier Ragueneau, Christopher Rabouille, Santosh Kumar Sarkar, Dennis P. Swaney, Paul Wassman, and Karen F. Wishner 


\section{Comparative biogeochemistry-ecosystem-human interactions on dynamic continental margins}

Lisa A. Levin ${ }^{1}$, Kon-Kee Liu ${ }^{2}$, Kay-Christian Emeis ${ }^{3}$, Denise L. Breitburg ${ }^{4}$, James Cloern $^{5}$, Curtis Deutsch ${ }^{6}$, Michele Giani ${ }^{7}$, Anne Goffart ${ }^{8}$, Eileen E. Hofmann ${ }^{9}$, Zouhair Lachkar $^{10}$, Karin Limburg ${ }^{11}$, Su-Mei Liu ${ }^{12}$, Enrique Montes ${ }^{13}$, Wajih Naqvi ${ }^{14}$, Olivier Ragueneau $^{15}$, Christophe Rabouille ${ }^{16}$, Santosh Kumar Sarkar ${ }^{17}$, Dennis P. Swaney ${ }^{18}$, Paul Wassman $^{19}$, Karen F. Wishner ${ }^{20}$

${ }^{*}$ Corresponding author Center for Marine Biodiversity and Conservation, Scripps Institution of Oceanography, 9500 Gilman Dr. La Jolla, CA 92093-0218, USA; 858534-3579; 1 levin@ucsd.edu),

${ }^{2}$ Institute of Hydrological and Oceanic Sciences, National Central University, Chungli, TAIWAN 320, kkliu@ncu.edu.tw

${ }^{3}$ Helmholtz-Zentrum Geesthacht, Institute of Coastal Research, Max-Planck-Str.1, 21502 Geesthacht, GERMANY; kay.emeis@hzg.de

${ }^{4}$ Smithsonian Environmental Research Center, PO Box 28647 Edgewater, MD 20676, USA, breitburgd@si.edu

${ }^{5}$ United States Geological Survey, 345 Middlefield Rd., Menlo Park, CA 94025, USA; jecloern@usgs.gov)

${ }^{6}$ School of Oceanography, University of Washington, Seattle, WA, 98195, USA, cdeutsch@uw.edu

${ }^{7}$ Instituto di Oceanografia e Geofisica Sperimentale (OGS), Via A. Piccard 5434151 Trieste, ITALY, mgiani@inogs.it

${ }^{8}$ Laboratoire d'Océanologie, Université de Liège, B6c, B 4000 Liège, Belgium \& STARESO, F 20260 Calvi, FRANCE; a.goffart@ulg.ac.be

${ }^{9}$ Center for Coastal Physical Oceanography, Old Dominion University, Norfolk, Virginia, 23508, USA, hofmann@ccpo.odu.edu

${ }^{10}$ Environmental Physics, Institute of Biogeochemistry and Pollutant Dynamics, ETH Zurich, Zurich, SWITZERLAND CHN E 23.1, Universitätstrasse 168092 Zürich, SWITZERLAND, zouhair.lachkar@env.ethz.ch

${ }^{11}$ Department of Environmental and Forest Biology, State University of New York College of Environmental Science and Forestry, Syracuse, NY 13210 USA, klimburg@esf.edu

${ }^{12}$ Key Laboratory of Marine Chemistry Theory and Technology Ministry of Education, Ocean University of China, Qingdao 266100, P. R. China, sumeiliu@ ouc.edu.cn.

${ }^{13}$ College of Marine Science, University of South Florida, St. Petersburg, Florida, USA, emontesh@mail.usf.edu

${ }^{14}$ National Institute of Oceanography, Goa, India, naqvi@nio.org.

${ }^{15}$ Laboratoire des Sciences de 1'Environnement Marin, Institut Universitaire Européen de la Mer, Technopôle Brest-Iroise, 29280 Plouzané, FRANCE ; olivier.ragueneau@univ-brest.fr

${ }^{16}$ Laboratoire des Sciences du Climat et de l'Environnement, Gif sur Yvette, France christophe.rabouille@1sce.ipsl.fr

${ }^{17}$ Department of Marine Science, University of Calcutta, 35 Ballygunge Circular Road, Calcutta 700019, INDIA, sarkar.santosh@gmail.com 
${ }^{18}$ Department of Ecology and Evolutionary Biology, Cornell University, Ithaca NY 14853, USA, dps1@cornell.edu USA

${ }^{19}$ Dept. of Arctic and Marine Biology, Faculty of Bioscience, Fishery and Economy, University of Troms $\varnothing, 9037$ Troms $\varnothing$, NORWAY, paul.wassmann@ uit.no

${ }^{20}$ University of Rhode Island, 215 S Ferry Rd, Narragansett, RI 02882, USA, kwishner@gso.uri.edu

\begin{abstract}
The ocean's continental margins face strong and rapid change, forced by a combination of direct human activity, anthropogenic $\mathrm{CO}_{2}$-induced climate change, and natural variability. Stimulated by discussions in Goa, India at the IMBER IMBIZO III, we (1) provide an overview of the drivers of biogeochemical variation and change on margins, (2) compare temporal trends in hydrographic and biogeochemical data across different margins (3) review ecosystem responses to these changes, (4) highlight the importance of margin time series for detecting and attributing change and (5) examine societal responses to changing margin biogeochemistry and ecosystems. We synthesize information over a wide range of margin settings in order to identify the commonalities and distinctions among continental margin ecosystems. Key drivers of biogeochemical variation include long-term climate cycles, $\mathrm{CO}_{2}$-induced warming, acidification, and deoxygenation, as well as sea level rise, eutrophication, hydrologic and water cycle alteration, changing land use, fishing, and species invasion. Ecosystem responses are complex and impact major margin services including primary production, fisheries production, nutrient cycling, shoreline protection, chemical buffering, and biodiversity. Despite regional differences, the societal consequences of these changes are unarguably large and mandate coherent actions to reduce, mitigate and adapt to multiple stressors on continental margins.
\end{abstract}

Keywords: anthropogenic factors, coastal biogeochemistry, climate change, eutrophication, ecosystem services, time series

Regional Terms: Continental margins, Europe, North Atlantic, North Pacific; Arctic 


\section{Introduction to dynamic margin ecosystems}

The oceans' continental margins extend for some 150,600 km (Jahnke, 2010) and encompass estuarine, open coast, shelf, canyon, slope, and enclosed sea ecosystems. They are both gateway and window to the open ocean, where water, nutrients, energy, sediments, contaminants and organisms meet and are transferred through land-margin and margin-open ocean interactions (Levin et al., 2001). The continental margins include proximal estuaries, bays, lagoons and banks, and distal shelves, slopes and marginal seas. These are susceptible to changes in biodiversity, water quality, and productivity and have been increasingly perturbed by human activities.

Margin ecosystems include hard and soft-substrate habitats ranging from structurally complex wetlands, kelp forests, coral reefs, rocky reefs and sand beaches, to sedimented estuaries, slopes and canyons. Most of the habitat volume, however, occurs in the overlying water column, with variation linked to water masses, circulation, and land and atmospheric interactions. As one crosses depth contours from estuaries across the shelf to the continental slope, steep gradients in nutrient concentrations, temperature, salinity, oxygen, $\mathrm{pH}$ and suspended matter are found that impact the productivity, composition, diversity, and abundance of organisms (Cloern, 1996; Hofmann et al., 2011; Levin and Sibuet, 2012). Relative to their area, the margins account for a disproportionately large fraction of the global primary production $(10-15 \%)$, nutrient recycling, carbon burial (> $60 \%$ of total settling organic carbon), and fisheries production (Walsh et al. 1988; Muller-Karger et al., 2005). They also are exceptionally dynamic systems with ecosystem structures that can oscillate slowly or shift abruptly, but rarely remain static.

The current continental margin seascape has been shaped extensively by climate change and human activities, yielding altered ecosystem services. Margin ecosystems provide key services in the form of physical protection from waves, storms, and floods, chemical buffering, food provisioning, nursery support, nutrient cycling, habitat fostering biodiversity, carbon sequestration, recreation, and aesthetic value. Finely tuned biogeochemical interactions drive these functions. Because human populations are disproportionately concentrated in coastal cities, there is heterogeneity in the human effects on margins, creating mosaics of heavily impacted and relatively pristine systems. Nutrient inputs, freshwater extraction, fishing, construction, species introductions, and contamination are but a few of the many ways humans alter coastal ecosystems. Also the steady increase of anthropogenic $\mathrm{CO}_{2}$ inputs to the atmosphere will result in significant changes in water column temperature, oxygenation, $\mathrm{pH}$, and productivity by 2100 , with major consequences for margin ecosystems and the over 1 billion people that depend on them for food, employment and revenue (Mora et al., 2013; FAO, 2012).

While margin research has a long history among oceanographers (Banner et al., 1980. Walsh et al., 1988, Biscaye et al., 1994, Duarte et al. 1999, Antia et al., 2001, Liu et al., 2010), a synoptic view of dynamic coupled margin systems has emerged more slowly and the linkages between human and natural biogeochemical variations, ecosystem response and human social structures are only now being explored. The interactive effects of remote forcing from distant inland activities, from atmospheric processes, and from 
physical processes far out to sea are becoming more apparent. There are, however, gaps in our understanding of the combined effects of multiple drivers on coastal biogeochemistry and ecosystems across all continental margins. The objectives of this paper are to provide an overview of sources of biogeochemical variation on margins, associated ecosystem responses, and the societal and policy implications, with a focus on lessons from multiple continental margin time series (Fig 1).

This paper reflects the themes and discussions of the continental margins working group of IMBER IMBIZO III (Goa, India in January 2013). In this paper we examine drivers of biogeochemical variation on margins, distinguishing natural from $\mathrm{CO}_{2}$-based climate variability, and more direct human drivers. We next compare temporal trends for multiple physical and biogeochemical parameters at geographically contrasting locations We then discuss the complex ecosystem responses to biogeochemical variation and trends on margins, in particular those related to warming, deoxygenation, acidification and hydrologic alterations. We subsequently identify the key roles played by continental margin time-series stations (Fig. 1) in identifying and attributing drivers of change and in understanding the associated ecosystem responses. Finally, we examine societal responses to changing margin biogeochemistry and ecosystems, highlighting areas where social and natural scientists must work together. Case studies (expanded in Supplement B) are synthesized to provide insights into the sensitivity of margins to natural and human perturbations, the ecological, social and economic consequences that stem from these perturbations, and the policy actions needed to mitigate impacts on coastal ecosystems and their resources.

\section{Natural and human-induced drivers of biogeochemical variation on margins}

Controls on biogeochemistry of margins are complex and dynamic. In this paper we distinguish drivers associated with natural variability, anthropogenic $\mathrm{CO}_{2}$-driven climate change and direct human (anthropogenic) impacts. It is often difficult to disentangle these three forcing mechanisms, as well as to distinguish local change from regional to global-scale pressures. Multiple factors act together - exerting top-down (often human) and bottom - up (natural or human) controls on ecosystem structure simultaneously.

\section{Natural Sources of Variability}

Natural variation in biogeochemical features affecting margin ecosystems occurs on a vast range of time scales, from millions of years to hours. Direct measurements during the past century in many of the systems discussed here have revealed large, abrupt, persistent changes in the structure and function (or state) of an ecosystem, which were sometimes interpreted as regime shifts (Mumby et al., 2007; de Young et al., 2008; Barnovsky et al. 2012). These may be manifested as simultaneous changes in phytoplankton, dominant consumer species, and trophic structure. Regime shifts often yield major consequences for fisheries and human livelihood (McFarlane et al., 2002; Zhang and Gong, 2005). Examples can be found in the North Pacific - Pacific Decadal Oscillation (Wooster and Zhang, 2004), North Atlantic (Alheit et al., 2014) Caribbean coral reefs (Hughes, 1994), Mediterranean Sea (Conversi et al., 2010), Northern Adriatic Sea (Conversi et al., 2009) and North Sea (Beaugrand, 2004). In the Northern Hemisphere, major ecosystem shifts were observed in the late 1980s to early 1990s, with 
synchronous shifts following an overall period of high variability. These ecosystem Conversi et al., 2010; Möllmann et al., 2011). It is cautioned that these abrupt changes are sometimes difficult to distinguish from random fluctuations or overfishing effects and their true nature often remains unclear (e.g., Hsieh et al., 2005).

Margins may also be subject to basin-specific and regional influences. For example, the California Cooperative Oceanic Fisheries Investigations (CalCOFI), one of the longest existing oceanographic time series (63 y), reveals major natural variations in water column temperature, oxygen, $\mathrm{pH}$ and current strength that are associated with changes in the regional hydrography of the California Current Ecosystem over multiple time and space scales (Checkley and Barth, 2009; McClatchie et al., 2010; Nam et al., 2011; Send and Nam 2012). In addition to the Pacific Decadal Oscillation, there are decadal scale ENSO cycles, seasonal and week-long upwelling events that alter productivity and/or ocean biogeochemistry with marked shifts in oxygen and pH (Fig 2). Variability in these environmental parameters results in changes in the regional biodiversity and ecosystem structure with significant impacts on ecosystem services we depend on (Doney et al. 2012).

Much natural climate variability and some manifestations of climate change occur abruptly over short time and space scales. Most margins experience episodic, extreme events that shape their ecosystems, often through biogeochemical modification. For example the Rhone River carries $80 \%$ of its solid flux during $5 \%$ of the time (Antonelli et al., 2007) with large biogeochemical consequences (Cathalot et al., 2010). Extreme storm events can reshape coastal systems with short-lived, dramatic changes in salinity and flushing rates and through more persistent alterations of channel openings (Paerl et al., 2001). Atmospheric deposition of nutrients associated with air mass outflow from the Indo-Gangetic Plain to the northern Bay of Bengal is significant and most can occur over 4 months in association with the NE monsoon, highlighting the temporal nature of these atmospheric drivers (Srinivas et al., this volume). These are likely to have direct consequences for eutrophication in Bay of Bengal surface waters triggering profuse algal blooms in the adjacent Sundarban wetland (Naha Biswas et al., 2013). Heat waves that last for a few weeks can induce mass mortality in coastal ecosystems of the Mediterranean Sea either directly (Garrabou et al., 2009; Marba and Duarte, 2010) or through the spread of disease and invasive species (Lejeusne et al., 2010).

As with short time scales, small areas of the ocean can play key roles in global biogeochemical fluxes on margins. For example, 1\% of the ocean's water volume accounts for $50 \%$ of $\mathrm{N}$ removal through water column denitrification and annamox in oxygen deficient zones (Deutsch et al., 2011), and 60-70\% of the annual denitrification rate occurs in shelf sediments (Codispoti, 2007). Submarine canyons carry $80-90 \%$ of the sediment and organic matter fluxes to the open seafloor sediments, with transport affected by climate-driven stratification, wind regime and winter cooling (Canals et al., 2006; Rabouille et al., 2013). It is proposed that the Congo River, with the second largest discharge in the world, carries $50 \%$ of the river's silica through an $800-\mathrm{km}$ long submarine canyon to a $3000 \mathrm{~km}^{2}$ deep-sea fan (Raimonet et al., this volume). The 
functions of submarine canyons as key removal agents via deep-sea fans and deltas may

228 be diminished by climate change-driven reduction of dense water formation with less

An important question to emerge is whether natural variability associated with exposure to stressful conditions (such as hypoxia or hypercapnia) confers evolutionary preadaptation to further stress from climate change or direct human activities. Evidence suggests that animals in margin settings subject to upwelled, low-pH waters are resilient to such conditions (e.g., Thomsen et al., 2010; Yu et al., 2011; Hoffmann et al., 2014). In other coastal regions where hydrographic variability is also intense and there are multiple controls from land, detection of trends, sources and biological responses including adaptation can be difficult (Duarte et al., 2013). Whether hydrographic stressors that vary naturally (oxygen, acidification and warming) elicit more adaptation than 'unnatural' (man made) trace organic or metal/metalloid contaminants, remains an open question.

\section{$\mathrm{CO}_{2}$-driven climate drivers}

Rising $\mathrm{CO}_{2}$ in the atmosphere is reshaping margin ecosystems by increasing sea level, ocean warming, ocean acidification and ocean deoxygenation (Doney et al. 2012). There are also climate shifts that alter patterns of heat, drought, precipitation, and flooding that modify margins directly and indirectly through changes in land use, runoff, and human activities.

$\mathrm{CO}_{2}$-induced warming and enhanced stratification have been linked to declining oxygen concentrations on the southern California shelf and upper slope (Bograd et al., 2008) as well as increased seasonal hypoxia on the inner Oregon shelf (Chan et al., 2008). These changes also involve lowered $\mathrm{pH}$ and high $\mathrm{pCO}_{2}$ (Frieder et al. 2012; Alin et al. 2012), with consequences for biogeochemical cycling and ecosystem structure in the California Current (CC) system (Doney et al. 2012). Upwelling is intensifying and low pH (which promotes aragonite undersaturation) is spreading in the northeast Pacific (Feely et al. 2008; Gruber et al., 2012). The observed low pH conditions in the CC system are shaping characteristics of this ecosystem by affecting calcifying species and have resulted in the decline of cultured bivalves (Barton et al., 2012). Whether the oxygen and $\mathrm{pH}$ changes reflect a continuous, secular trend resulting from $\mathrm{CO}_{2}$-driven climate changes or are part of a larger (50 y) natural cycle remains controversial (McClatchie et al. 2010; Deutsch et al., 2011). These changes are occurring in an ecosystem already subject to high natural variability (Fig. 2). Clear understanding of this complexity is needed for forecasting future conditions.

Beyond upwelling regions, perhaps the greatest manifestations of climate change are found on the shelves of the Arctic Ocean. Among the most massive of inputs, a full 10\% of the freshwater reaching the oceans occurs in the Arctic, which has only 4 million people living there. Thawing of permafrost due to warming yields increased inputs of soil organic carbon and methane to the coastal ocean and atmosphere (Schurr, 2013), and will influence many aspects of the Arctic coastal ecosystem (Whiteman et al., 2013). The freshwater from melting sea ice combined with degradation of released organic matter is causing major perturbation of low $\mathrm{pH}$ in the Arctic. Baseline monitoring of the W. Arctic 
Ocean reveals that $20 \%$ of the Canada Basin surface waters exhibit aragonite undersaturation (Robbins et al., 2013).

As temperatures continue to increase (Behrenfeld et al., 2006), warming is expected to reduce productivity over much of the ocean (Mora et al., 2013). It is uncertain whether sinking phytoplankton and respiration of vertical migrators), counteracting the deoxygenation effects of global warming (from increased stratification and reduced mixing). Alternatively, intensified upwelling in a warmer world may pump more nutrients into surface waters, increase respiration of microbes and other organisms, and increase the rate of deoxygenation. As a direct effect or through changes in currents such as the Gulf Stream, warming might increase methane emissions via dissociation of gas hydrates on continental margins (Phrampus and Hornbach, 2012). Massive gas hydrate deposits in the shallow Arctic Ocean are particularly susceptible and their release may exacerbate acidification and oxygen depletion via aerobic methane oxidation in the water column (Biastoch et al., 2011). There has yet to be exploration of modern biological responses to long-term increases in methane fluxes on margins, although the geologic past may hold lessons in this regard (Kennett et al., 2003).

\section{Direct Human Drivers}

Rivers are a primary conduit of nutrient loading to the shelf from terrestrial sources of nutrients. Since the development in the early 20th century of the Haber-Bosch process for fixing nitrogen for use in fertilizers, the global nitrogen cycle has become increasingly affected by anthropogenic inputs. The net anthropogenic nitrogen inputs (NANI) to a region include fertilizer application, atmospheric deposition, agricultural $\mathrm{N}$ fixation by leguminous crops, and the nitrogen associated with food and livestock feed crossing regional boundaries. Nitrogen flux in rivers is often highly correlated to the NANI of their drainage basins (e.g., Howarth et al., 1996; Han and Allen, 2008; Swaney et al., 2012). In areas of high population densities (e.g., coastal cities) or regions of industrialscale livestock production, as is increasingly seen in India and China, the nitrogen associated with the trade of food and feed commodities may be very significant. In areas of high crop production, synthetic $\mathrm{N}$ fertilizer is typically the dominant source of $\mathrm{N}$ (e.g., Yan et al., 2010). In India, use of synthetic fertilizer has grown exponentially over the last fifty years, making Indian agriculture one of the most intense consumers of fertilizer in the world (Swaney et al., this issue). Between 1970 and 2000, the coastal Bay of Bengal has experienced massive $\mathrm{N}$ and $\mathrm{P}$ loading (50\% and 35\% increase, respectively) causing eutrophication; 70-80\% of the loading is from agricultural sources (Sattar et al., 2014).

Margins play a key role in filtering nutrients and contaminants that enter the ocean via runoff and rivers. Productive estuarine ecosystems, particularly wetlands, are able to remove nutrients by denitrification, uptake by vascular plant, phytoplankton, and microbes, by promoting flocculation and enhancing deposition and burial (Kennedy 1984, Howarth et al., 2006; Dähnke et al., 2008; Lassaletta et al., 2011; Howarth et al., 2012). Intensive filter feeding by bivalves such as oysters and mussels can also remove particulate nutrients and control eutrophication (Cloern et al. 1982; Dame 2012). The 
filtering functions of margins have been greatly affected by massive wetland loss over the oysters) and species introductions (of invasive bivalves) have also had a major influence on water filtration functions (Dame 2011).

Human acceleration of nutrient cycles and eutrophication are among the best studied of the anthropogenic forcing factors and cause the most conspicuous adverse effects upon continental margins as witnessed by diverse case studies (Table 1, Fig. 1). Intensified nitrogen loading is widespread in coastal ecosystems receiving effluents from catchments with dense human populations (Rabalais, 2004; Glavovic et al., submitted). This yields continental margin dead zones (coastal hypoxic areas resulting from eutrophication), which number over 475 and are on the rise (Diaz and Rosenberg, 2008; World Resources Institute, 2013). The largest of these occur in the Baltic Sea, the Black Sea, the northern Gulf of Mexico and the East China Sea (Rabouille et al., 2008; Zhu et al., 2011), where historical hypoxia induced by natural climate conditions and circulation has been exacerbated by human nutrient input (Zillén et al. 2008; Rabalais et al., 2010; K.-K. Liu et al., this issue). The relative importance of natural and human (nutrient) drivers and efficacy of nutrient legislation has been under debate in recent years (e.g., Bianchi et al., 2008). For example, shrinking of hypoxic areas in the Black Sea appears to have resulted from reductions in human agricultural nutrient inputs, though the extent of the human impacts on this ecosystem is still not clear (Mee et al., 2005). In addition, as indicated above, the balance between $\mathrm{N}, \mathrm{P}$ and $\mathrm{Si}$ is being modified by many factors that affect coastal production, both qualitatively and quantitatively (Ragueneau et al., 2005). $\mathrm{CO}_{2^{-}}$ driven changes in warming, winds, upwelling, and precipitation will inevitably influence both the intensity and areal cover of hypoxia in many dead zones (Rabalais et al., 2009, 2014; Giani et al., 2012).

\section{Comparisons across continental margins}

To gain a broader sense of how shelf systems are responding to climatic forcing and direct human activities we have compared multiple physical and biogeochemical observations collected at geographically contrasting locations (Fig. 3, Table 2). Consistent with the global warming trend, three out of five margins (the Cariaco Basin, East China Sea and North Sea) have shown increasing temperatures over the last four decades (slope $=\mathrm{X}^{\circ} \mathrm{C} \mathrm{yr}^{-1} ; p<0.01$ ), except for San Francisco Bay (slope $=-0.029^{\circ} \mathrm{C}$ $\mathrm{yr}^{-1} ; p=0.07$ ) where a cooling trend has been detected (For more detail see Supplement A). The cooling trend observed in San Francisco Bay is attributed to an increase in upwelling intensity accros the entire California Curruent system resulting from increasing northerly wind stress along the western coast of the US (Chavez et al., 2011). The warming trend in the Cariaco Basin, in turn, is the result of the weakening of the Trade Winds, and thus of upwelling intensity, along the southern Caribbean Sea (Astor et al., 2013; Taylor et al., 2012).

No significant trends in sea surface salinity (SSS) are observed at the Cariaco Basin or the North Sea. SSS in the Bohai Sea, however, shows a positive trend $\left(0.0632 \mathrm{yr}^{-1}\right)$ (Fig. 
$3 b)$. The increasing salinity of the Bohai Sea is thought to be caused by decreasing freshwater discharge from the Yellow River (Fig. 3d).

The load of dissolved inorganic nitrogen (DIN) in Changjiang (aka the Yangtze River), which empties into the East China Sea, has increased by over two-fold (Liu et al., 2014) between 1970 and 2002 (Fig. 3c), while this river's freshwaterwater discharge has only increased slightly (Fig. 3d). This suggests that rising DIN concentrations in the Changjiang River is mainly due to the intensive use of chemical fertilizer (Yan et al., 2010). By contrast, and due to EU policy change, the DIN load discharged to the North Sea has decreased by 50\% since 1977. Dissolved inorganic phosphorus (DIP) shows a similar decreasing trend at this location (Pätsch and Lenhart, 2011)

The sea surface chlorophyll- $a$ concentrations in SF Bay have increased in the last two decades (Fig. 3e), which is consistent with the observed decreasing trend in SST . Simultaneously, however, chlorophyll- $a$ in the Cariaco Basin shows a decreasing trend since the late 90's due to weaker upwelling events and stronger thermal stratification (Taylor et al., 2012). The monthly mean sea surface chlorophyll- $a$ in the East China Sea derived from ocean color products by NASA's Sea-viewing Wide Field-of-view Sensor (SeaWiFS) also exhibits a significant increasing trend since 1998, which is thought to result from increased DIN loads from the Changiiang River (Fig. 3c) (K.-K. Liu et al., this issue).

In response to increasing phytoplankton growth, bottom water oxygen saturation in SF Bay and the East China Sea has shown a significant decline (Fig. 3f). Oxygen saturation shows a weak decline in the upper $3 \mathrm{~m}$ at the CARIACO Station (Fig 3f), probably due to warming and possibly to lower oxygen production by phytoplaknton (Fig 3e).

Different margins show markedly different responses to local stressors and to globalscale change. Variations in availability and temporal coverage of different environmental parameters highlight the need for comprehensive and sustained time-series observations on continental margins. These are required in ordert to understand ecosystem responses to natural, $\mathrm{CO}_{2}$ climate-driven and direct human perturbations.

\section{Ecosystem responses to biogeochemical change on continental margins}

Some of the most apparent environmental and ecosystem consequences due to the common climate and human stressors discussed in this special issue are summarized in Table 1 and discussed below.

Human alteration of hydrological processes such as damming and water diversion (B3, B4), drives very noticeable physical changes in margins causing loss of habitats due to coastal erosion or reduced river discharge (e.g., S.M. Liu, this issue). When combined with climate effects, resulting salinity increases can lead to species invasions that reshape coastal ecosystems. Following massive water diversion and drought in San Francisco Bay, an invasion by Asian clams altered the timing and magnitude of phytoplankton availability, with cascading trophic consequences (Cloern and Jassby, 2012, B3). In the 
Bay of Brest, introduction of an invasive limpet changed the seasonality of primary production, which in turn has changed benthic biodiversity and completely modified the

In a broad sense, land use change alters how rainfall interacts with the landscape. Some land-use activities result in increased soil degradation and erosion (i.e., agriculture, mining), and in eutrophication of rivers and continental margins through the use of fertilizers. The coastal zone's high primary productivity and the abundant filter feeders (e.g., Lotze et al., 2006) offset land-derived nutrient inputs to some extent, but are tested by eutrophication and overfishing (B2). Moreover, rising sea levels will lead to flooding of low-lying coastal regions like India and Bangladesh, movement of seawater farther up estuaries, and intrusion of seawater into groundwater reservoirs.

Eutrophication is among the most widespread of coastal insults (Table 1; B2, B3, B4, B5, B6), but the outcomes, which include productivity enhancement and hypoxia, can be complex. For example, several cross-system comparisons indicate that increased $\mathrm{N}$ enhances total landings of fish and mobile shellfish even in systems with hypoxia (Fig. 4), although individual species may decline and the overall composition of the catch can be affected (Nixon and Buckley, 2002; Breitburg et al., 2009b). On the downside, hypoxia - an endocrine disrupter in fish that experience chronic exposure (Thomas et al., 2006) - can favor gelatinous plankton and some bivalves (Breitburg et al., 2003), and create and eliminate shallow water refuges for small and juvenile fishes (Breitburg et al. 2009a).

Reversal of eutrophication trends have been observed in some areas such as the Danish straits (Carstensen et al., 2006), the Scheldt Estuary (Soetaert et al., 2006) and other continental European rivers discharging into the North Sea (Emeis et al., this volume), the open Northern Adriatic (Giani et al., 2012), and the NW Black Sea (McQuatterGollop et al., 2009). In some instances $P$ reduction has been considered to be a primary driver of these changes. In the areas subject to oligotrophication, overfishing may act synergistically to diminish the trophic chain and reduce seafood resources (B5). However, along the Danish and Finnish coasts, dissolved oxygen in bottom waters continues to drop despite efforts to reduce nutrient discharge (Carstensen et al., 2014). In the Baltic Sea, which hosts nearly $20 \%$ of the world's identified coastal hypoxic sites, climate and nutrient drivers interact with regional circulation patterns and wastewater treatment technologies to produce a mosaic of faunal responses (Conley et al., 2011).

While eutrophication-induced hypoxia is spreading, warming also causes the ocean to lose oxygen due to the synergistic effect of reduced oxygen solubility and enhanced water column stratification (Bopp et al., 2001). This has been termed deoxygenation and contributes to global expansion of oxygen minimum zones (Stramma et al. 2010). Recent model results demonstrate the extreme sensitivity of the volume of suboxic water in the open ocean to changing climate conditions (Deutsch et al., 2011). Biological analyses suggest that equator-ward species boundaries are highly sensitive to changes in ocean temperature and oxygen content. Models predict a decline in metabolic scope of species (energy available for maintenance and reproduction) and functional habitat loss. 
On margins both eutrophication and intensified upwelling typically increase production while drawing down oxygen and creating hypoxia at deeper water levels. Animal avoidance of hypoxia acts to aggregate species around or above hypoxic zones, and leads to habitat compression, both in estuarine settings and in open-ocean oxygen minimum zones (OMZs). The resulting aggregations are susceptible to overfishing (Craig, 2012, Breitburg et al., 2009b), but high catches may mask the consequences of ecosystem stress, making detection of habitat degradation difficult (Breitburg et al., 2009b). Such conditions also induce shoaling of the zooplankton biomass layer at the thermocline (upper oxycline boundary) and concentration of midwater biomass in a layer at the lower oxycline (Wishner et al., 2013). As oxygen declines and oxygen minima shoal in both the Atlantic and Pacific, large billfish are now found at shallower depths and are increasingly susceptible to overfishing (Prince and Goodyear, 2006; Prince et al., 2010; Stramma et al., 2011).

Upwelling margins, which host key world fisheries, exhibit strong vertical gradients in temperature, oxygen and $\mathrm{pH}$ associated with oxygen minimum zones (Paulmier et al., 2011). Across these gradients bathyal benthic assemblages reveal shifts in diversity, body size, zonation, carbon processing, bioturbation, colonization and resilience (Levin, 2003, Levin et al. 2009; Gilly et al., 2013; Levin et al., 2013). Intensified upwelling is predicted to result in changes in biodiversity and ecosystem functioning associated with the expansion of OMZs (Stramma et al., 2010; Gilly et al., 2013). Recent onset of seasonal hypoxia on the Oregon inner shelf now causes summer die-offs of fish and invertebrates (Grantham et al., 2004). Responses to intensified upwelling winds and increased stratification can also vary regionally. For example, comparative analyses of the California and Canary systems reveal substantial differences in the responses of biological production and air-sea $\mathrm{CO}_{2}$ fluxes to upwelling intensification in these two systems (Lachkar and Gruber, 2013). These differences have been attributed to various drivers such as the contrasting shelf topography, eddy activity, coastal water residence times and basin-scale forcing in the two regions (Marchesiello and Estrade, 2009; Lachkar and Gruber, 2013). These differences also affect the vulnerability of these ecosystems to global anthropogenic perturbations such as ocean acidification (Lachkar, 2014). Other upwelling regions have received less attention and could exhibit additional (or alternative) response mechanisms.

$\mathrm{CO}_{2}$-induced climate change is the predominant forcing on the ecosystem of the polar margins (S8). Warming of the Arctic is taking place two to three times faster than global rates (Trenberth et al., 2007); as a result sea-ice cover has been decreasing at a rate of $>10 \%$ per decade with ice-free summers expected in a few decades. Arctic ecosystems are increasingly being challenged by tipping elements (Duarte et al., 2012; Naam, 2012; Wassmann and Lenton, 2012). In the future Norway may experience decreased primary productivity, while Russia will show increased productivity. Nowhere will adaptation be a more critical element of sustainability than in the Arctic, because the Arctic shelves have inordinate importance in feeding the world population. (See S8 for more details)

Among the many effects of rising atmospheric $\mathrm{CO}_{2}$, the significant decrease of ocean $\mathrm{pH}$ (ocean acidification) and shift in seawater carbonate chemistry (Doney et al., 2001) may 
elicit some of the most economically significant responses from margin ecosystems. Acidification alters seawater chemical speciation, most notably the lowering of calcium carbonate saturation states, which impacts shell-forming marine organisms from plankton to benthic molluscs, echinoderms, and corals, all of which are abundant in continental margins. Ocean acidification is exacerbated in the coastal zone by increased land-derived nutrient inputs, which enhance, in turn, productivity of organic matter and therefore respiration and release of $\mathrm{CO}_{2}$ (e.g., Borges and Gypens, 2010; Cai et al., 2011). A serious drop of aragonite saturation state has occurred in some coastal seas, such as the North Yellow Sea, threatening the aquaculture of shellfish (e.g., Zhai et al., 2014). Coral reef ecosystems, which provide key fisheries, critical shoreline protection and habitats for a large number of species, are highly susceptible (Andersson and Gledhill, 2013). Due to ocean acidification, rates of coral calcification may decrease, whereas rates of bioerosion and carbonate dissolution may increase, resulting in a transition from net accretion to net erosion. Impairment of the calcifying capacity of marine organisms is therefore expected to have negative impacts on coral reefs and other calcifiers (e.g., bivalves) and on the ecosystem services they provide.

The complexity of ocean biogeochemical-ecosystem interactions on margins means that some drivers will create responses that generate feedback - further altering a system. One example occurs when acidification-induced undersaturation of carbonate minerals adversely affects shell growth and settlement success of bivalves and coral polyps building reefs; this is predicted to ultimately reduce oyster, mussel and clam populations and coral reef building. Locally, the presence of large oyster populations buffers increasing $\mathrm{CO}_{2}$ and decreasing $\mathrm{pH}$ through shell dissolution and alkalinity increase. So lowered $\mathrm{pH}$ ultimately reduces local buffering capacity, leading to further reductions in $\mathrm{pH}$ when the mineral buffer is exhausted. In addition, mass removal of shellfish (by harvest), could contribute to a deficit in the carbonate balance, as the shells form a dissolution buffer needed by many animals to survive (Waldbusser et al., 2013). Populations may be reduced to the point of unsustainability leading to 'recruitment overfishing'.

On some margins high-frequency climate oscillations are the dominant driver of biogeochemical variation and consequently, ecosystem structure. In the Bay of Calvi in the Ligurian Sea of the NW Mediterranean (Goffart et al., this issue) the biogeochemical condition is very oligotrophic during mild winters and mesotrophic during moderate winters (B7). During severe winters, the Bay sustains a "high nutrient - low chlorophyll" situation. With little human disturbances this Bay may serve as the baseline, against which ecosystem changes in the Mediterranean due to direct human impacts can be detected (see B7 for more details). In the East Pacific Ocean, interannual variations linked to ENSO induce low productivity (well oxygenated) El Nino and high productivity (low oxygen) La Nina conditions that affect fisheries production in the Humboldt and California and Benguela current ecosystems (Arntz et al., 2006).

\section{Using time series to distinguish drivers of change}

Hydrographic and ecological time series have provided data critical to evaluating and interpreting change on margins. Koslow and Couture (2013) have referred to ecological 
time series as the Cinderella (hard working drudges) at the climate change ball. Beyond this they may provide the "Anthropocene's canary in a coal mine" for many other forms of human disturbance. Below we address the approaches, benefits and limitations of time series in attribution of change on margins.

Several multi-decadal oceanographic time series measurements from a variety of coastal and pelagic systems have shown how lower and intermediate trophic levels, and biogeochemical cycling react to climate oscillations regionally and globally (Chavez et al., 2003; Black et al., 2011; Church et al., 2013) (Table 1). Multi-decadal time series of phytoplankton have been generated for many regions including San Francisco Bay (Cloern and Jassby, 2013), Chesapeake Bay (Lee et al., 2013), Narragansett Bay (Borkman and Smayda, 2009), the Cariaco Basin (Chavez et al., 2011, Muller-Karger et al., 2013), the North Sea (Wiltshire et al., 2008) and areas of the Mediterranean Sea (e.g. Goffart et al., 2002, Ninčević Gladan et al., 2010, Zingone et al., 2010, Goffart et al., submitted) including the Northern Adriatic (Bernardi-Aubry et al., 2012, Marić et al., 2012, Mozetič et al., 2012) and Gulf of Naples (Ribera d'Alcalà et al., 2004). There are also Arctic time series in the Bering, Chukchi, and Barents Sea. Most of these reveal oscillations associated with climate variability (Borkman et al., 2009; Harrison et al., 2010). Indeed, such long-term ocean time series have been fundamental for expanding our knowledge about the sensitivity of marine biodiversity, ecosystems and biogeochemistry to environmental change (Church et al., 2013; Koslow and Couture, 2013). However, moving forward an international network of time series is needed to evaluate regional linkages and interpret global changes.

There are some major gaps in time series monitoring. Whereas models of nutrient fluxes from watersheds abound, monitoring data to verify them do not. In the developing world, the scarcity of monitoring data adequate to characterize riverine nutrient flows has impeded our understanding of the relationships with human activities. Research and development of monitoring in these regions, should be made a priority, and would improve our management of coastal waters. It is important to add that not only the $\mathrm{N}$ cycle should be monitored, but also changes in nutrient ratios delivered by rivers. In particular the Si:N and Si:P ratios should be closely monitored as potential early warning indicators of disturbances (Billen and Garnier, 2007); indeed, they are often decreasing due to excessive $\mathrm{N}$ and $\mathrm{P}$ inputs and decreasing Si inputs due to damming (Humborg, 1997) and the proliferation of invasive species (Ragueneau et al., 2005) causing replacement of diatoms by dinoflagellates. South East Asia, where anthropogenic factors leading to decreasing $\mathrm{Si}: \mathrm{N}$ and $\mathrm{Si}: \mathrm{P}$ ratios combine, should be especially targeted for monitoring (Ragueneau et al., 2006).

Modern time series gain added value when used in conjunction with paleooceanographic studies (Black et al., 2011) and models (see Church et al., 2013); together these tools allow researchers to discern natural sources of environmental change from variations induced by climate change (warming, extreme flooding from river input or snow melt, or heat waves) and direct human drivers such as eutrophication, damming and fishing (Koslow and Couture, 2013). In some margin settings subject to long bouts of habitation and industrialization (e.g., Chesapeake Bay, the coastal SE North Sea, northern Adriatic), 
natural variability is a small signal relative to the influence of humans. In others (e.g., upwelling margins) natural variability produces an exceedingly strong signal and irrefutably detecting $\mathrm{CO}_{2}$-driven climate change or anthropogenic forcing is difficult.

Sediment and glacial ice core climate records often provide the long temporal perspective needed to identify climate oscillations prior to high anthropogenic $\mathrm{CO}_{2}(>280 \mathrm{ppm}$ ) conditions or resulting from long-term changes in human population density and land use practices (Cooper and Brush, 1993; Emeis et al., 2000; Yasuhara et al., 2012). Some of these geological climate records are now complemented by oceanographic and biogeochemical time series observations, thus providing valuable insights into the effects of anthropogenic perturbations on the marine environment (see Black et al., 2011).

Time Series and Coastal Management. The motivation underlying the establishment of ecological time series varies. In California, CalCOFI was developed in the 1950s to understand the boom and bust cycles of the sardine (Bograd et al., 2003; Chavez et al., 2003). At its inception, the CalCOFI concept of monitoring the entire ecosystem, now widely accepted in the context of ecosystem-based management, was visionary and somewhat heretical. In Chesapeake Bay, a long time series of young-of-year fish abundances in Maryland waters was initiated in 1954 by the state fisheries agency to aid management of several anadromous species (Durrell and Weedon, 2011), a time series of jellyfish abundances was begun in 1960 by a University of Maryland researcher in response to the 'Jellyfish Nuisance Act' (Cargo and King, 1990), and bay-wide time series monitoring of water quality parameters was begun in the 1980s with funding from the States of Maryland and Virginia and the US EPA to aid management efforts to improve water quality conditions (Boesch et al., 2001). Governments of states bordering the western coasts of Europe (OSPAR) and the Baltic Sea (HELCOM) initiated monitoring programs in the 1970's to protect the marine environment from all sources of pollution through intergovernmental cooperation.

Although each time series is fixed in space and provides local information, when data are combined across time series they can provide a powerful synoptic understanding of the link between climate variability and ocean biogeochemistry (Church et al, 2013). The ICES Phytoplankton and Microbial Plankton Status Report 2009/2010 exemplifies this for the North Atlantic (O'Brien et al., 2012). Records of sea ice cover and tipping points in the Arctic provide another example (Carstensen and Weydmann, 2012). Under optimal conditions, time series provide data prior to catastrophe (e.g., fishery collapse) so that causes can be discerned. It is important, however, to recognize the value of understanding regional differences and their forcing mechanisms.

Time series constraints. Spatially fixed time series may have limitations. Single-location measurements typically do not reveal spatial expansions, contractions or oscillations. They cannot recognize change due to relocation of organisms or features, making it difficult in some cases to untangle spatial and temporal change, although spatial comparisons can sometimes be used as proxies of temporal change (e.g., Wishner et al., 2013). Satellite remote sensing has typically been the tool of choice for extrapolating fixed time series observations to broader spatial and temporal scales. Some time-series stations (i.e., Hawaiian Ocean Time-series [HOT] and the Bermuda Atlantic Time Series 
[BATS]) have been successful at using autonomous samplers and sensors (e.g., gliders, drifting profilers) for learning the regional significance of the measurements they collect. These are especially important for hard-to-reach areas like the Arctic and Antarctic, and can expand coverage for traditional time series in other regions. Autonomous sampling platforms, however, are expensive to operate and thus are out of reach for time-series programs with limited resources. Another approach is to engage platforms of opportunity. Industry with a presence on the ocean margins, such as offshore wind and aquaculture, fishing, fossil fuel extraction and minerals, may have a role to play in time series development in the future, and should be broadly engaged to support monitoring efforts. Expansion of programs like the World Ocean Council Smart Data/Smart Industries (http://www.oceancouncil.org/site/smart_ocean.php) may be useful.

Time, funding and facilities constraints often limit time series to the upper water column and basic hydrographic parameters. To link these to key resource needs and sustainable management - including aquaculture, fisheries, energy and minerals - it will be necessary to incorporate the sea floor and its organisms into time-series monitoring. Benthos monitoring can also provide critical information about biogeochemical feedbacks from the sea floor, processes often not included in large-scale climate or ecosystem models.

Most margin time series are not of sufficient duration to detect variation outside normal statistical variability (especially given decadal-scale cycles emerging in the atmospheresurface ocean system). Often shifts and change are misattributed due to lack of knowledge about natural variability and its sources. Paleoceanographic records in ice cores, sediment cores or tree rings allow us to extend understanding of margin processes back in time, prior to the establishment of in situ observations (Gooday et al. 2009). Innovative analyses of scales, teeth, otoliths and ichnofacies may allow use of such records to reconstruct complex changes in exposure histories and food web dynamics (Gooday et al., 2009; Morat et al., 2014). Recent development of geochemical proxies for detection of fish exposure to hypoxia offers the promise of identifying past and present trends in oxygen concentration using otoliths (Limburg et al., 2011; 2014 [this volume]); fish scales and other skeletal elements may also prove useful, but require testing. Chronosequences from long-lived calcifying organisms (e.g., coldwater corals or bivalves) may provide excellent time series of temperature or $\mathrm{pH}$ as a basis for chronometric analyses similar to dendrochronology (e.g., Chauvaud et al., 2005, 2012; Black et al., 2008). Novel functional gene microarrays may be used to evaluate the diversity and composition of the denitrifying microbial community in hypoxic settings like OMZs, allowing us to better understand how microbial metabolism can impact the global climate through the production of $\mathrm{N}_{2} \mathrm{O}$, a bi-product of denitrification and a powerful greenhouse gas (Jayakumar et al., 2013). We need to further develop proxy variables for environmental reconstructions, expand the data bases for regional-scale hindcasts, and strive to detect and interpret interannual variability from low resolution archives.

While valuable in having fixed measurements, time series may also need to have an adaptive observation component focused on (a) identifying changes and their underlying causes and (b) monitoring parameters tied to the ecosystem services we care about, in order to directly address policy concerns for effective management of these services. 
There is often a gap between what we can realistically measure, and what we want to achieve. This highlights the importance of research on basic processes and mechanisms that will identify indicators of change and incorporate process-based knowledge into our models. Often the early warning of degradation will come from land. For example, agricultural inputs, nutrient concentrations, N:P, Si:P , Si:N ratios or multiple nutrient concentration data together could be key indicators (Billen and Garnier, 2007).

The burgeoning number of time series and rising volumes of data highlight a need to engage more scientists in the analysis phase of time series research. There is also a challenge of maintaining continuity in the face of severe funding shortages; scientists must advocate for continuation of monitoring programs. Key to the successful continuation of time series is concise presentation of insight gained and raising the awareness of the public and policy makers of their value. It is here that social scientists can help natural scientists learn how to make a strong case without loss of integrity and accountability.

\section{The continental margin in the Anthropocene: the convergence of biogeochemistry, ecosystems and society}

To be effective, economic models must be able to weigh the costs of the unwanted impacts of stressors and forcings on ecosystem services discussed above and associated consequences against gains for society, and to attribute change to specific and controllable drivers. To date scientists have failed to convey the message of the overriding importance and societal consequences of $\mathrm{CO}_{2}$ emissions (as well as other greenhouse gases) in the context of global warming. Investment in collaboration efforts between social and natural scientists, development of outreach and public communication skills, and advocacy about the importance of individual actions are required to manage margins effectively (Pidgeon and Fischhoff, 2011). A need to combine scientific with traditional and local ecological knowledge, especially in settings such as the Arctic, further argues for key social-natural science integration.

There is growing need for modeling of coupled human (social)-biogeochemical systems on margins. A pioneering example can be found for the surfclam fishery on the Middle Atlantic Bight (MAB) continental shelf (McCay et al., 2011). This million-dollar fishery has been managed since the 1990s with transferable quotas, one of the first in the US to do so. In recent decades the population has shifted to the north and overall abundance has declined (Weinberg, 2005). Simulations of surfclam growth that use 50-year hindcasts of bottom temperature obtained from an implementation of the Regional Ocean Modeling System for the MAB (Kang and Curchister, 2013) show that episodic warming events increase surfclam mortality and limit animal size in the southern portion of its range (Narváez et al, this issue). The resulting northward movement of the stock has negative economic consequences for the fishing fleet and processing plants. These studies point to a key role for natural scientists in assessment of the socio-economic consequences of climate change (McCay et al., 2011).

Disasters can sometimes serve as catalysts for action. In the United States, several disaster events have caught the attention of the scientific community and policy makers, 
and have resulted in the development of large-scale monitoring efforts that seek to mechanistically understand these events and mitigate their impacts by improving our predicting capabilities. One example is the unexpected failure of the oyster aquaculture fishery on the US Pacific coast due to upwelling of carbonate-undersaturated waters (Barton et al., 2012); this stimulated state-sponsored research programs on ocean acidification (Adelsman and Binder, 2012). Highly destructive Superstorm Sandy stimulated sea level rise preparedness, and massive fish kills resulting from hurricaneinduced release of hog waste and sewage in North Carolina (Malin et al., 1999) have engendered public support for altered agricultural practices and backup treatment plants. These types of events are not one-time occurrences, but are likely to become more frequent. For example, low bottom-water aragonite saturation values on shelves are expected to have negative effects on shellfish in the Yellow Sea (Zhai et al., 2014) and off California (Gruber et al., 2012). The costs required for building community, industry and ecosystem resilience are now being weighed against the massive costs of disaster damage and disaster relief.

While continued and expanded time series measurements are essential to monitor status and trends, scientists often know enough to make strong policy recommendations regarding $\mathrm{CO}_{2}$, nutrients and human activities. In many instances adaptation to change is required and distinguishing among drivers is not essential for policy decisions. Whether reduced sediment inputs to the coastal zone result from damming or from drought, it will still be necessary to prepare for climate-related sea level rise and associated consequences of limited land-building and net loss of coastal wetlands. For anadromous fishes, loss of freshwater inputs from damming versus drought will have similar consequences, as will loss of river-sea connectivity from eutrophication induced hypoxia versus upwellinginduced deoxygenation. For coastal shellfish, the corrosive effects of acidification may result from atmospheric $\mathrm{CO}_{2}$ inputs, intensified upwelling, increased stratification, anthropogenic nutrient loads, precipitation or sea ice melting. Acting to reduce $\mathrm{CO}_{2}$ emissions and limit the now-inevitable rise in ocean temperatures, acidification, and deoxygenation is critical.

There is growing consensus that direct anthropogenic stressors such as overexploitation of natural resources (fisheries, mining), habitat destruction, land use/cover change, alteration of river catchments, coastal construction, damming, species invasion and pollution will lower the resilience of populations, species and ecosystems and make them less able to cope with climate-induced stress (Bijma et al., 2013). For example, reducing fishing mortality in exploited populations can also reduce total mortality and be protective of declining populations, even where part of that total mortality was due to hypoxia, disease or habitat degradation (Breitburg et al., 2009b). Thus policy, law and management of margins must consider and address climate and direct human stressors together. Relevant lessons can be drawn from regional, time series and case studies where different combinations of stressors interact and their trends have been tracked over time. Understanding system connectivities, seeking indicators of regime change, and promoting adaptation-oriented policy to build functional resilience, are lessons from the Arctic (Carmack et al., 2012) that apply well to most margin ecosystems. The recently released IPCC AR5 report emphasizes the overwhelming need for societal adaptation to 
multiple stressors associated with climate change, especially in countries where poverty will exacerbate the consequences (Field et al. IPCC 2014).

The recognition of the importance of natural capital and ecosystem services to national wealth has come slowly to some nations. In the USA this is now evidenced by the generation of a National Ocean Policy (2004; http://iocunesco.org/images/stories/LawoftheSea/Documents/NationalOceanPolicy/nop.usa.pdf). To a large extent this policy addresses the continental margins, where most of the key services and commercial resources are provided. The Marine Strategy Framework Directive (Directive 2008/56/EC, http://ec.europa.eu/environment/water/marine/ges.htm), adopted by the European Commission in 2008, marks an important milestone in the development of the EU's marine environmental policy and is the first framework instrument aimed expressly at protecting and preserving the marine environment with a holistic approach. In 2012 The EU launched its Blue Growth initiative (http://ec.europa.eu/maritimeaffairs/policy/blue growth/) that addresses three crucial components of sustainable development of marine resources: gathering and channeling marine knowledge to improve access to information about the continental margins of Europe, maritime spatial planning to aid management of offshore resources, and integrated maritime surveillance. Other nations have national ocean policies in review (e.g., South Africa) or in early stages of formulation (Namibia).

Margin management strategies must move from mono- to multiple stressor considerations. Most policies and research programs address only one or two factors nutrients, oxygen, ocean acidification, fishing pressure, disease, or invasive species, (e.g., Crain et al., 2008). We know that $\mathrm{T}, \mathrm{O}_{2}$ and $\mathrm{CO}_{2}$ are changing simultaneously and interacting (Bijma et al., 2013). There is need for scientific consensus on a) what the multistressor questions are and $b$ ) how to approach the issues. How to integrate laboratory studies, field observations, monitoring, modeling, and use of proxies to address these questions remains a major challenge.

To incorporate natural variability and climate change into our decision making and management activities we need research that identifies, quantifies and confronts management tradeoffs. Stakeholder identification and finding equitable solutions is critical as every decision has winners and losers. We must quantify the economic costs of nutrient reduction for agriculture, fishers, and ecosystem services. Margin researchers have only just begun to tackle the larger question of valuing ecosystem services and biodiversity on the continental slope beyond the shelf -this is especially critical in deep waters where resource extraction activities (energy, minerals and deep-water fishing) are on the rise (Levin and Dayton, 2009; Jobstvogt et al., 2013).

As both top predators and guardians of the planet we face immense ocean policy challenges over the next 10-50 years. The mentality of many nations is of a land-based society. Managing a fluid -connected environment is fundamentally different than managing land use where discrete boundaries between impacted and more pristine areas can be maintained. There is a spatial disconnect between farm policies and their effects 
on the coastal ocean and our margins. Even international climate negotiations (Converence of Parties) involve remarkably little consideration of ocean processes, despite the large role the ocean plays in regulating climate. The concepts underlying sustainability in ocean margins must involve an educational thrust that starts early, as well as strategies to communicate at national and international levels. We need to better understand the process by which science is introduced to policy, and target and fast track scientific approaches that meet those needs. End-to-end efforts are needed that first bring together the natural and human component of socio-ecosystems; and then work with stakeholders and policy makers towards finding and implementing solutions.

This article focuses on the impacts of the $20^{\text {th }}$ century; we recognize that the $21^{\text {st }}$ century may involve a different suite of primary stressors, some of which are as yet unknown. The continental margins of the future will undergo further changes as the system is continuously perturbed. As human populations grow, needs for fresh water, energy, space, and food will create new demands of the coastal ocean including coastal aquaculture, wind farms, wave energy stations and desalinization plants, intensified shipping activities, and seabed mineral exploration.

Holistic consideration of margins facing the confluence of human, climate and natural stressors highlights the need to integrate science with societal needs. Building on work of others (e.g., Islam and Tanaka, 2004), we identify the need to:

- Formulate a clear understanding of the environmental, ecological and economic value of margin ecosystems and how these vary under different climate regimes.

- Enact water quality management that recognizes land-ocean-atmosphere exchanges controlled by climate and humans.

- Enact comprehensive monitoring to link policy-based changes in drivers to ecosystem responses

- Improve cooperation of stakeholders, regulators, scientists and civil society

- Scale and coordinate local, regional, national and international activities to maximize knowledge and promote modeling efforts

- Protect key services via ecosystem-based management

- Develop mechanisms to translate scientific knowledge into regulation and legislation, and the political realities needed to achieve action.

Ultimately, we will need to set priorities, accept tradeoffs and motivate creative solutions. These goals are very much in line with the approach of the Future Earth Initiative to meet the grand challenge of global sustainability (Reid et al., 2010). Interactions among social and natural scientists are nascent, but a growing number of national and international programs recognize their importance. Achieving sufficient energy, water, food and healthy margin ecosystems is a tall order, but a challenge that natural and social scientists must work together to meet head on.

\section{Acknowledgements}

We are grateful for the hospitality of the National Institute of Oceanography, Goa, India, which hosted the IMBIZO III. Support for the workshop was provided by IMBER (a core 
project of IGBP), SCOR and a host of co-sponsors. We thank two anonymous reviewers for their comments which have improved the manuscript. L. Levin's and D. Breitburg's attendance was supported by the US Ocean Carbon Biogeochemistry program and

IMBER. Levin's research support is from NOAA - California Sea Grant College Program Project \# R/CC-04 and NSF OCE 0927445 and 1041062. Support for E. Hofmann was provided by NSF grant GEO-0908939. Support for K.-K. Liu was provided by the Ministry of Science and Technology, Taiwan, and SCOR.

\section{References}

Adelsman, H., and Binder, L. W. (Eds.) (2012) Washington State Blue Ribbon Panel on Ocean Acidification (2012): Ocean Acidification: From Knowledge to Action, Washington State's Strategic Response, Washington Department of Ecology, Publication no. 12-01-015, Olympia, Washington.

Alheit, J. Licandro, P, Coombs, S., Garcia, A., Giráldez, A., Santamaría, M., Slotte, A., Tsikliras, A. Atlantic Multidecadal Oscillation (AMO) modulates dynamics of small pelagic fishes and ecosystem regime shifts in the eastern North and Central Atlantic, Journal of Marine Systems, Volume 131, March 2014, Pages 21-35, ISSN 0924-7963, http://dx.doi.org/10.1016/j.jmarsys.2013.11.002.

Alin, S. R., Feely, R. A., Dickson, A. G., Hernandez-Ayon, J. M., Juranek, L. W., Ohman, M. D., and Goericke, R. (2012) Robust empirical relationships for estimating the carbonate system in the southern California Current System and application to CalCOFI hydrographic cruise data (2005-2011), Journal of Geophysical Research 117, C05033.

Andersson, A.J., Gledhill, D., (2013). Ocean acidification and coral reefs: Effects on breakdown, dissolution, and net ecosystem calcification. Annual Review of Marine Science, 5: 321-348

Antia, Avan, Maßßen, J., Herman, P., Voß, M., Scholten, Jan, Groom, S. and Miller, P. (2001) Spatial and Qualitative Patterns of Particle Flux at the European Continental Margin: The OMEX I Project Deep-Sea Research Part II-Topical Studies in Oceanography, 48 (14-15). pp. 3083-3106.

Arntz, W.E., V.A. Gallardo, D. Guteierrez, E. Isla, L.A. Levin, J. Mendo, C. Neira, G. Rowe, J. Tarazona and M. Wolff. (2006) ENSO and similar perturbation effects on the benthos of the Humboldt, California and Benguela Current upwelling ecosystems. Advances in Geosciences 6, 243-265.

Astor, Y.M., Lorenzoni, L., Thunell, R., Varela, R., Muller-Karger, F., Troccoli, L., Taylor, G.T., Scranton, M.I., Tappa, E., Rueda, D., (2013) Interannual variability in sea surface temperature and fCO2 changes in the Cariaco Basin. Deep-Sea Res. II, doi:10.1016/j.dsr2.2013.01.002.

Banner, F.T., Collins, M.E., Massey, M.S. (Eds) (1980) The North-West European Shelf Seas: The Sea Bed and the Sea in Motion II. Physical and Chemical Oceanography, and Physical Resources. Elsevier Oceanography Series, Volume 24, Part B, 301-638.

Barnosky, A.D., Hadly, E.A., Bascompte, J., Berlow, E.L., Brown, J.H., Fortelius, M., Getz, W.M., Harte, J., Hastings, A., Marquet, P.A., Martinez, N.D., Mooers, A., Roopnarine, P., Vermeij, G., Williams, J.W., Gillespie, R., Kitzes, J., Marshall, 
C., Matzke, N., Mindell, D.P., Revilla, E., Smith, A.B., 2012. Approaching a state shift in Earth's biosphere. Nature, 486, 52-58, doi:10.1038/nature11018.

Barton, A., Hales, B., Waldbusser, G.G., Langdon, C., and Feely, R.A. (2012) The Pacific oyster Crassostrea gigas, shows negative correlation to naturally elevated carbon dioxide levels: implications for near-term ocean acidification effects. Limnol. Oceanogr.57, 698-710

Beaugrand, G. (2004) The North Sea regime shift: evidence, causes, mechanisms and consequences, Progress in Oceanography 60, 245-262.

Behrenfeld, M. J., R. T. O’Malley, D. A. Siegel, C. R. McClain, J. L. Sarmiento, G. C. Feldman, A. J. Milligan, P. G. Falkowski, R. M. Letelier and E. S. Boss (2006) "Climate-driven trends in contemporary ocean productivity." Nature 444, 752 755.

Bernardi Aubry, F., Cossarini, G., Acri, F., Bastianini, M., Bianchi, F., Camatti, E., De Lazzari, A., Pugnetti, A., Solidoro, C., Socal, G. (2012) Plankton communities in the northern Adriatic Sea: patterns and changes over the last 30 years. Estuarine, Coastal and Shelf Science 115, 125-137

Bianchi, T. S., Dimarco, S. F., Allison, M. A., Chapman, P., Cowan, J. H., Hetland, R. D., \& Rowe, G. (2008) Controlling hypoxia on the US Louisiana shelf: Beyond the nutrient- centric view. Eos, Transactions American Geophysical Union, 89(26), 236-237.

Biastoch, A., Treude, T., Rupke, L. H., Riebesell, U., Roth, C., Burwicz, E. B., Park, W., Latif, M., Boning, C. W., and Madec, G. (2011) Rising Arctic Ocean temperatures cause gas hydrate destabilization and ocean acidification, Geophysical Research Letters 38.

Bijma, J., Portner, H.-O., Yesson, C., and Rogers, A. D. (2013) Climate change and the oceans-What does the future hold?, Marine Pollution Bulletin 74, 495-505.

Billen G., Garnier J., (2007) River basin nutrient delivery to the coastal sea: Assessing its potential to sustain new production of non-siliceous algae. Marine Chemistry 106, $148-160$

Biscaye, P. E., Flagg, C. N., and Falkowski, P. G. (1994) The shelf edge exchange processes experiment, SEEP-II: an introduction to hypotheses, results and conclusions, Deep Sea Research Part II: Topical Studies in Oceanography 41, 231-252.

Black, B.A., G.W. Boehlert, and M. Yoklavich. (2008) Establishing climate-growth relationships for yelloweye rockfish (Sebastes ruberrimus) in the northeast Pacific using a dendrochronological approach. Fisheries Oceanography 17, 368-379.

Black, D., R. Thunell, K. Wejnert, and Y. Astor (2011) Carbon isotope composition of Caribbean Sea surface waters: Response to the uptake of anthropogenic $\mathrm{CO}_{2}$, Geophys. Res. Lett., 38, L16609, doi:10.1029/2011GL048538.

Boesch, DF, RB Brinsfield and RE Magnien. (2001) Chesapeake Bay eutrophication. Journal of Environmental Quality 30, 303-320

Bograd, S. J., Castro, C. G., Di Lorenzo, E., Palacios, D. M., Bailey, H., Gilly, W., and Chavez, F. P. (2008) Oxygen declines and the shoaling of the hypoxic boundary in the California Current, Geophysical Research Letters 35. 
Bograd, S. J., Checkley, Jr, D. A., and Wooster, W. S. (2003) CalCOFI: A half century of physical, chemical, and biological research in the California Current System, Deep Sea Research Part II: Topical Studies in Oceanography 50, 2349-2353.

Bopp, L., Le Quere, C., Heimann, M., Manning, A.C., Monfray, P., 2002. Climateinduced oceanic oxygen fluxes: Implications for the contemporary carbon budget. Global Biogeochemical Cycles, 16(2) 10.1029/2001gb001445

Borges, A. V. and N. Gypens (2010). "Carbonate chemistry in the coastal zone responds more strongly to eutrophication than to ocean acidification." Limnology and Oceanography 55(1): 346-353.

Borkman, D., H. Barreta-Bekker and P. Henriksen eds. (2009) Long-term phytoplankton time series. Journal of Sea Research 61, (1\& 2).

Borkman, D.G., Smayda, T. (2009) Multidecadal (1959-1997) changes in Skeletonema abundance and seasonal bloom patterns in Narragansett Bay, Rhode Island, USA. Journal of Sea Research 61, 84-94.

Breitburg, D. L., Adamack, A., Rose, K. A., Kolesar, S. E., Decker, B., Purcell, J. E., Keister, J. E., and Cowan, J. H. (2003) The pattern and influence of low dissolved oxygen in the Patuxent River, a seasonally hypoxic estuary, Estuaries 26, 280-297.

Breitburg, D. L., Hondorp, D. W., Davias, L. A., and Diaz, R. J. (2009b) Hypoxia, nitrogen, and fisheries: integrating effects across local and global landscapes, Annual Review of Marine Science 1, 329-349.

Breitburg, DL, JK Craig, RS Fulford, KA Rose, WR Boynton, DC Brady, BJ Ciotti, RJ Diaz, KD Friedland JD Hagy 111, DR Hart, AH Hines, ED Houde, SE Kolesar, SW Nixon, JA Rice, DH Secor and TE Targett. (2009a) Nutrient enrichment and fisheries exploitation: interactive effects on estuarine living resources and their management. Hydrobiologia 2009, 31-47

Caballero-Alfonso, A. et al. (2013) Regional variability of hypoxia in the coastal Baltic Sea. This volume

Cai, W.J. et al., (2011). Acidification of subsurface coastal waters enhanced by eutrophication. Nature Geoscience, 4(11): 766-770

Canals, M., Puig, P., Durrieu de Madron, X., Heussner, S., Palanques, A., Fabres, J., (2006). Flushing submarine canyons. Nature 444, doi:10.1038/nature05271.

Cargo, D.G. and King, D. R. (1990) Forecasting the abundance of the sea nettle, Chrysaora quinquecirrha, in the Chesapeake Bay. Estuaries 13, 486-491.

Carmack, E., McLaughlin, F., Whiteman, G., Homer-Dixon, T. (2012) Detecting and coping with disruptive shocks in Arctic marine systems: a resilience approach to place and people. AMBIO (2012) 41:56-65 DOI 10.1007/s13280-011-0225

Carstensen J, Weydmann A. (2012) Tipping points in the arctic: eyeballing or statistical significance? Ambio. 2012 Feb;41(1):34-43. doi: 10.1007/s13280-011-0223-8.

Carstensen, J., Conley, D.J., Andersen, J.H., Frtebjerg, G., (2006) Coastal eutrophication and trend reversal: a Danish case study. Limnology and Oceanography 51 (1e2), $398 \mathrm{e} 408$.

Carstensen, J., et al. (2014). "Hypoxia in the Baltic Sea: Biogeochemical Cycles, Benthic Fauna, and Management." AMBIO 43(1): 26-36.

Cathalot, C., Rabouille, C., Pastor, L., Deflandre, B., Viollier, E., Buscail, R., Gremare, A., Treignier, C., Pruski, A.,( 2010). Temporal variability of carbon recycling in 
coastal sediments influenced by rivers: assessing the impact of flood inputs in the Rhone River prodelta. Biogeosciences 7, 1187-1205.

Chan, F., Barth, J., Lubchenco, J., Kirincich, A., Weeks, H., Peterson, W., and Menge, B. (2008) Emergence of anoxia in the California Current large marine ecosystem, Science 319, 920-920.

Chauvaud L., Dunbar R., Lorrain A., Paulet Y.-M., Thouzeau G., Jean F., Guarini J. -M., Mucciarone D. (2005) The shell of the great scallop Pecten maximus as a high frequency archive of paleoenvironmental change. Geochemistry Geophysics Geosystems 6, Q08001

Chauvaud L., Patry Y., Jolivet A., Cam E., Le Goff C., Strand Ø., Charrier G., Thébault J., Lazure P., Gotthard K., Clavier J. (2012) Variation in size and growth of the great scallop Pecten maximus along the latitudinal gradient. PLoS ONE 7,e37717

Chavez, F. P., Messie, M., and Pennington, J. T. (2011) Marine primary production in relation to climate variability and change, Annual Review of Marine Science 3, 227-260.

Chavez, F.P., Ryan, J., Lluch-Cota, S.E., Niquen C., M., (2003) From Anchovies to Sardines and Back: Multidecadal Change in the Pacific Ocean. Science 299,(5604), 217-221.

Checkley Jr., D. M., and Barth, J. A. (2009) Patterns and processes in the California Current System, Progress in Oceanography 83, 49-64.

Church, M. J., M. W. Lomas, and F. E. Muller-Karger. (2013) Sea Change: Charting the course for biogeochemical ocean time series research in a new millennium. DeepSea Research, Part II: Topical Studies in Oceanography 93, 2-15.

Cloern, J.E. (1982) Does the benthos control phytoplankton biomass in South San Francisco Bay (USA)?: Marine Ecology-Progress Series 9,191-202

Cloern, J. E., and Jassby, A. D. (2012) Drivers of change in estuarine-coastal ecosystems: Discoveries from four decades of study in San Francisco Bay, Reviews of Geophysics 50.

Cloern, J.E., (1996) Phytoplankton bloom dynamics in coastal ecosystems : a review with some general lessons from sustained investigation of San Francisco Bay, California. Reviews of Geophysics 34, 127-168.

Conley, D.J. and 18 others. (2011) Hypoxia is increasing in the coastal zone of the Baltic Sea. Env. Sci. and Technol. Lett. 45, 6777-6783.

Conversi, A., Fonda-Umani, S., Peluso, T., Molinero, J.C., Santojanni, A., Edward, M. (2010) The Mediterranean Sea regime shift at the end of the1980s, and intriguing parallelisms with other European Basins. PLOS ONE 5 (5), e10633. http:// dx.doi.org/10.1371/journal.pone.0010633.

Conversi, A., Peluso, T., Fonda-Umani, S. (2009) Gulf of Trieste: A changing ecosystem. Journal of Geophysical Research, 114, C03S90, doi:10.1029/2008JC004763, 2009

Cooper, S. R., and Brush, G. S. (1993) A 2,500-year history of anoxia and eutrophication in Chesapeake Bay, Estuaries 16, 617-626.

Craig, J. K. (2012) Aggregation on the edge: effects of hypoxia avoidance on the spatial distribution of brown shrimp and demersal fishes in the Northern Gulf of Mexico. Marine Ecology Progress Series 445, 75-95.) 
Crain, C. M., Kroeker, K., and Halpern, B. S. (2008) Interactive and cumulative effects of multiple human stressors in marine systems, Ecology Letters 11, 1304-1315.

Dähnke, K., E. Bahlmann and K.-C. Emeis (2008) A nitrate sink in estuaries? An assessment by means of stable nitrate isotopes in the Elbe estuary. Limnol. Ocean. 53(4), 1504-1511.

Dame, R. (2012) Bivalve Filter Feeders: in Estuarine and Coastal Ecosystem Processes. Springer Publishing Co.

Dame, R. (2011). Ecology of Marine Bivalves: An Ecosystem Approach. CRC Press, Boca Raton, FL.

Deutsch, C., Brix, H., Ito, T., Frenzel, H., and Thompson, L. (2011) Climate-forced variability of ocean hypoxia, Science 333, 336-339.

deYoung, B., Barange, M., Beaugrand, G., Harris, R., Perry, R. I., Scheffer, M., and Werner, F. (2008) Regime shifts in marine ecosystems: detection, prediction and management, Trends in Ecology \& Evolution 23, 402-409.

Diaz, R.J., Rosenberg, R., (2008) Spreading dead zones and consequences for marine ecosystems. Science 321, 926-929.

Doney, S., Ruckelshaus, M., Duffy, J.E., Barry, J.P., F. Chan, C.A. English, H.M. Galindo, J.M. grebmeier, A. B. Hollowed, N. Knowlton, J. Polovina, N. Rabalais, W.Sydeman and L. Talley. 2012. Climate change impacts on marine ecosystems. Annu. Rev. Mar. Sci. 2012. 4:11-37

Doney, S.C., Fabry, V.J., Feely, R.A., Kleypas, J.A., (2009) Ocean Acidification: The Other $\mathrm{CO}_{2}$ Problem. Annual Review of Marine Science, 1: 169-192

Duarte, C. M., Hendriks, I. E., Moore, T. S., Olsen, Y. S., Steckbauer, A., Ramajo, L., Carstensen, J., Trotter, J. A., and McCulloch, M. (2013) Is ocean acidification an open-ocean syndrome? Understanding anthropogenic impacts on seawater $\mathrm{pH}$, Estuaries and Coasts, 1-16.

Duarte, C.M., Agustí, S., Kennedy, H., Vaqué, D. (1999) The Mediterranean climate as a template for Mediterranean marine ecosystems: the example of the NE Spanish littoral. Progress in Oceanography 44, 245-270.

Duarte, C.M., Agusti, S., Wassmann, P., Arrieta, J.M, Alcaraz, M., Coello, A., Marba, N., Hendriks, I.E., Holding, J., Garcia-Zarandona, I., Kritzberg, E., Vaque, D. (2012) Tipping elements in the Arctic marine ecosystem, Ambio 41, 44-55.

Durell, EQ and C Weedon. (2011) Striped bass seine survey juvenile index web page. http://www.dnr.state.md.us/fisheries/juvindex/index.html. Maryland Department of Natural Resources, Fisheries Service

Emeis, K., J. van Beusekom, U. Callies, R. Ebinghaus, A. Kannen, G. Kraus, I. Kröncke, H. Lenhart, I. Lorkowski, V. Matthias, C. Möllmann, J. Pätsch, M. Scharfe, H. Thomas, R. Weisse and E. Zorita (submitted) The North Sea - a shelf sea in the Anthropocene. Journal of Marine Systems (this volume).

Emeis,K.-C., Struck, U., Leipe,T., Pollehne,F., Kunzendorf,H., Christiansen,C. (2000) Changes in the C, N, P burial rates in some Baltic Sea sediments over the last 150 years - relevance to $\mathrm{P}$ regeneration rates and the phosphorus cycle. Marine Geology, 167, (1-2), 43-59

Feely, R.A., Sabine, C.L., Hernandez-Ayon, J.M., Ianson, D., Hales, B. (2008) Evidence for upwelling of corrosive "acidified" water onto the continental shelf. Science 320, 1490-1492. 
Frieder, C., Nam, S., Martz, T., and Levin, L. (2012) High temporal and spatial variability of dissolved oxygen and $\mathrm{pH}$ in a nearshore California kelp forest, Biogeosciences 9, 3917-3930.

Garrabou, J., Coma, R., Bensoussan, N., Bally, M., Chevaldonne, P., Cigliano, M., Diaz, D., Harmelin, J. G., Gambi, M., and Kersting, D. (2009) Mass mortality in Northwestern Mediterranean rocky benthic communities: effects of the 2003 heat wave, Global Change Biology 15, 1090-1103.

Giani, M., Djakovac, T., Degobbis, D., Cozzi, S., Solidoro, C., and Umani, S. F. (2012) Recent changes in the marine ecosystems of the northern Adriatic Sea, Estuarine, Coastal and Shelf Science 115, 1-13.

Gilly, W.F., Beman, J.M., Litvin, S.Y. and B.H. Robison. (2013) Oceanographhic and biological effects of shoaling of the oxygen minimum zone. Ann. Rev. Mar. Sci. 5, 21.1-21.28

Glavovic, B.C. et al., 2014. Living on the Margin in the Anthropocene: Engagement Arena for Global Sustainability Research and Action. Science: (Submitted).

Goffart, A., Hecq, J. H., and Legendre, L. (submitted) Drivers of phytoplankton bloom in the oligotrophic Bay of Calvi (NW Mediterranean) : results from a long-term study (1979-2011), Progress in Oceanography.

Goffart, A., Hecq, J.-H., and Legendre, L. (2002) Changes in the development of the winter-spring phytoplankton bloom in the Bay of Calvi (NW Mediterranean) over the last two decades: a response to changing climate?, Marine Ecology Progress Series 236, 45-60.

Gooday, A.J., Jorissen, F., Levin, L.A., Middelburg, J.J, Naqvi, W., Rabalais, N., Scranton, M., Zhang, J. (2009) Historical records of coastal eutrophication and hypoxia Biogeosciences 6, 1-39.

Grall, J; Chauvaud, L (2002) Marine eutrophication and benthos: the need for new approaches and concepts. Global Change Biology, 8: 813-830

Grantham, B. A., F. Chan, K. J. Nielsen, D. S. Fox, J. A. Barth, A. Huyer, J. Lubchenco, and B. A. Menge (2004), Upwelling-driven nearshore hypoxia signals ecosystem and oceanographic changes in the northeast Pacific, Nature 429(6993), 749-754, doi:10.1038/nature02605.

Gren, I.-M., 2013. The economic value of coastal waters as nutrient filters for the Baltic Sea. Reg Environ Change, 13: 695-703.

Gruber, N., and Sarmiento, J. L. (1997) Global patterns of marine nitrogen fixation and denitrification, Global Biogeochemical Cycles 11, 235-266.

Gruber, N., Hauri, C., Lachkar, Z., Loher, D., Frolicher, T. L., and Plattner, G.-K. (2012), Rapid progression of ocean acidification in the California Current System, Science 337, 220-223.

Han, H., and Allan, J. D. (2008), Estimation of nitrogen inputs to catchments: comparison of methods and consequences for riverine export prediction, Biogeochemistry 91, 177-199.

Harrison, P.,A. Zingone and E. Phlips ed. (2010) Phytoplankton time series. Estuaries and Coastal Ecosystems, vol. 33,

Hofmann, E.E., B. Cahill, K. Fennel, MAM Friedrichs, K Hyde, C Lee, A. Mannino, RG Najjar, JE O'Reilly, J Wilkin, J Xue, (2011) Modeling the dynamics of continental shelf carbon. Annual Review of Marine Science 3, 93-122. 
Hofmann, G.E. , T. G. Evans, M. W. Kelly, J. L. Padilla-Gamiño, C. A. Blanchette, L.Washburn, F. Chan, M. A. McManus, B. A. Menge, B. Gaylord, T. M. Hill, E. Sanford, M. LaVigne, J. M. Rose, L. Kapsenberg, and J. M. Dutton. 2014. Exploring local adaptation and the ocean acidification seascape - studies in the California Current large marine ecosystem. Biogeosciences, 11, 1053-1064 Howarth, R. W., Billen, G., Swaney, D., Townsend, A., Jaworski, N., Lajtha, K., Downing, J., Elmgren, R., Caraco, N., and Jordan, T. (1996) Regional nitrogen budgets and riverine $\mathrm{N} \& \mathrm{P}$ fluxes for the drainages to the North Atlantic Ocean: Natural and human influences, Biogeochemistry 35, 75-139.

Howarth, R., Swaney, D., Billen, G., Garnier, J., Hong, B., Humborg, C., Johnes, P., Morth, C.-M., and Marino, R. (2012) Nitrogen fluxes from the landscape are controlled by net anthropogenic nitrogen inputs and by climate, Frontiers in Ecology and the Environment 10, 37-43.

Howarth, R., Swaney, D., Boyer, E., Marino, R., Jaworski, N., and Goodale, C. (2006) The influence of climate on average nitrogen export from large watersheds in the Northeastern United States, Biogeochemistry 79, 163-186.

Hsieh, C. H., Glaser, S. M., Lucas, A. J., Sugihara, G. (2005) Distinguishing random environmental fluctuations from ecological catastrophes for the North Pacific Ocean. Nature 435, 336-340.

Hughes, TP. (1994) Catastrophes, phase shifts, and large-scale degradation of a Caribbean coral reef. Science 265, 1547-1551

Humborg C, Ittekkot V, Cociasu A, Von Bodungen B (1997) Effect of Danube River dam on Black Sea biogeochemistry and ecosystem structure. Nature 386, 385-388

IPCC (2014). Field et al. Climate Change 2014 : Impacts Adaptation and Vulnerability. Summary for Policymakers (Copyright Pending).

Islam, S., and Tanaka, M. (2004) Impacts of pollution on coastal and marine ecosystems including coastal and marine fisheries and approach for management: a review and synthesis, Marine Pollution Bulletin 48, 624-649.

Jahnke, R. (2010), Global synthesis, in Carbon and Nutrient Fluxes in Continental Margins: A Global Synthesis, edited by K.-K. Liu, L. Atkinson, R. Quinones and L. Talaue-McManus, pp. 597-616.

Jayakumar, A., Peng, N., and Ward, B. (2013) Denitrifying communities in oceanic oxygen deficient zones using microarray analyses, IMBIZO III: The future of marine biogeochemistry, ecosystems and societies, IMBER, Goa, India.

Jobstvogt, N., Hanley, N., Hynes, S., Kenter, J., and Witte, U. (2013) Twenty thousand sterling under the sea: Estimating the value of protecting deep-sea biodiversity, Ecological Economics 97, 10-19.

Kennedy, V.S., 1984. The estuary as a filter. ????

Kennett, J. P., Cannariato, K. G., Hendy, I. L., and Behl, R. J. (2003) Methane hydrates in Quaternary climate change: The clathrate gun hypothesis, American Geophysical Union.

Koslow, J. A., and Couture, J. (2013) Ocean science: Follow the fish, Nature 502, 163164.

Lachkar, Z. (2014) Effects of upwelling increase on ocean acidification in the California and Canary Current systems, Geophys. Res. Lett., 40, doi:10.1002/2013GL058726. 
Lachkar, Z., and Gruber, N. (2013), Response of biological production and air-sea CO2 fluxes to upwelling intensification in the California and Canary Current Systems, Journal of Marine Systems 109, 149-160.

Lassaletta, L., Romero, E., Billen, G., Garnier, J., Garcia-Gomez, H., and Rovira, J. (2012), Spatialized N budgets in a large agricultural Mediterranean watershed: high loading and low transfer, Biogeosciences 9, 57-70.

Lee, YJ, WR Boynton, M Li and Y Li. (2013) Role of late wnter-spring wind influencing summer hypoxia in Chesapeake Bay. Estuaries and Coasts 36, 683-696

Lejeusne, C., Chevaldonne, P., Pergent-Martini, C., Boudouresque, C. F., and Perez, T. (2010) Climate change effects on a miniature ocean: the highly diverse, highly impacted Mediterranean Sea, Trends in Ecology \& Evolution 25, 250-260.

Levin, L. A. (2003) Oxygen minimum zone benthos: adaptation and community response to hypoxia, in Oceanography and Marine Biology, an Annual Review, Volume 41: An Annual Review, edited by R. Gibson and R. Atkinson, pp. 1-45.

Levin, L. A., and Dayton, P. K. (2009) Ecological theory and continental margins: where shallow meets deep, Trends in Ecology \& Evolution 24, 606-617.

Levin, L. A., and Sibuet, M. (2012) Understanding continental margin biodiversity: a new imperative, Annual Review of Marine Science 4, 79-112.

Levin, L. A., Boesch, D. F., Covich, A., Dahm, C., Erseus, C., Ewel, K. C., Kneib, R. T., Moldenke, A., Palmer, M. A., and Snelgrove, P. (2001) The function of marine critical transition zones and the importance of sediment biodiversity, Ecosystems 4, 430-451.

Levin, L., Ekau, W., Gooday, A., Jorissen, F., Middelburg, J., Naqvi, W., Neira, C., Rabalais, N., and Zhang, J. (2009) Effects of natural and human-induced hypoxia on coastal benthos, Biogeosciences Discussions 6, 3563-3654.

Levin, L.A., C. Frieder, M. Navarro, J. Gonzalez, T. Martz. (2013) Hypoxia, hypercapnia and homosapiens on upwelling margins. Oral Presentation, IMBER IMBIZO III, Goa, India, Jan. 2013.

Limburg, K.E., C. Olson, Y. Walther, D. Dale, C. Slomp, and H. Høie (2011) Tracking Baltic hypoxia and cod migration over millennia with natural tags. Proceedings of the National Academy of Sciences of the U.S. doi:10.1073/pnas.1100684108.

Limburg, K.E., B.D. Walther, Z. Lu, G. Jackman, J. Mohan, Y. Walther, A. Nissling, P.K. Weber, and A.K. Schmitt (2014) In search of the dead zone: use of otoliths for tracking fish exposure to hypoxia. Journal of Marine Systems. DOI: 10.1016/j.jmarsys.2014.02.014

Limburg, K. E., Walther, B. D., Lu, Z., Jackman, G., Mohan, J., Walther, Y., Nissling, A., Weber, P. K., and Schmitt, A. K. (submitted), In search of the dead zone: use of otoliths for tracking fish exposure to hypoxia.

Liu, K.-K., Yan, W., Lee, H.-J., Chao, S.-Y., Gong, G.-C., Yeh, T.-Y. (this issue) Impacts of increasing dissolved inorganic nitrogen discharge from Changjiang on primary production and sediment oxygen consumption in the East China Sea from 1970 to 2002. J. Mar. Syst.

Liu, K.K., Atknison, L., Quinones, R., Talaue-McManus, L. (Eds) (2010) Carbon and nutrient fluxes in continental margins: A global synthesis. Springer, Heidelberg Germany, 744 pp. 
Liu, S. M. (submitted, this issue) Response of nutrient transports to human activities in the ecosystem of the Bohai: under the influence of artificial floods.

Liu, S., Zhang, J., Gao, H., and Liu, Z. (2008) Historic changes in flux of materials and nutrient budgets in the Bohai, Acta Oceanologica Sinica 27, 1-17.

Mallin, M. A., Posey, M. H., Shank, G. C., McIver, M. R., Ensign, S. H., and Alphin, T. D. (1999) Hurricane effects on water quality and benthos in the Cape Fear watershed: natural and anthropogenic impacts, Ecological Applications 9, 350362.

Marba, N. and C.M. Duarte (2010) Mediterranean warming triggers seagrass (Posidonia oceanica) shoot mortality. Global Change Biology, 16, 2366-2375.

Marchesiello, P., and P. Estrade (2009) Eddy activity and mixing in upwelling systems: A comparative study of Northwest Africa and California regions, Int. J. Earth Sci., 98, 299-308, doi:10.1007/s00531-007-02356.

Marić, D., Kraus, R., Godrijan, J., Supić, N., Djakovac, T., Precali, R. (2012) Phytoplankton response to climatic and anthropogenic influence in the northeastern Adriatic during the last four decades. Estuarine, Coastal and Shelf Science 115, 98-112.

McCay, BJ, S. Brandt, C. Creed (2011) Human dimensions of climate change and fisheries in a coupled system: the Atlantic surfclam case. ICES J. Mar. Sci. (2011) 68 (6): 1354-1367. doi: 10.1093/icesjms/fsr044

McClatchie, S., Goericke, R., Cosgrove, R., Auad, G., and Vetter, R. (2010) Oxygen in the Southern California Bight: multidecadal trends and implications for demersal fisheries, Geophysical Research Letters 37, L19602.

McFarlane, G. A., Smith, P. E., Baumgartner, T. R., and Hunter, J. R. (2002) Climate variability and Pacific sardine populations and fisheries, American Fisheries Society Symposium 32, 195-214.

McQuatter-Gollop, A., Gilberrt, A.J., Mee, L.D., Vermaat, J.E., Artioli, Y., Humborg, C., Wulff, F., (2009) How well do ecosystem indicators communicate the effects of anthropogenic eutrophication? Estuarine, Coastal and Shelf Science 82, 583e596.

Mee, L. D., Friedrich, J., and Gomoiu, M. T. (2005) Restoring the Black Sea in times of uncertainty, Oceanography, 18, 100-111

Möllmann, C., Conversi A., Edwards M. (2011) Comparative analysis of European wide marine ecosystem shifts: a large-scale approach for developing the basis for ecosystem-based management. Biology Letters 7, 484-486.

Montes, E., Lomas, M., Muller-Karger, F. E., and Lorenzoni, L. (in prep) Responses of the N cycle in the Tropical and Sub-tropical North Atlantic to modern climate variability, Global Biogeochemical Cycles.

Mora, C., Wei, C.-L., Rollo, A., Amaro, T., Baco, A. R., Billett, D., Bopp, L., Chen, Q., Collier, M., and Danovaro, R. (2013) Biotic and Human Vulnerability to Projected Changes in Ocean Biogeochemistry over the 21st Century, PLoS Biology 11, e1001682.

Morat, F., Letourneur, Y., Dierking, J., Pecheyran, C., Bareille, G., Blamart, D., Harmelin-Vivien, M.L., (2014). The great melting pot. Common sole population connectivity assessed by otolith and water fingerprints. PlosOne 9, e86585. doi:86510.81371/journal.pone.0086585. 
Mozetič, P., Francé, J., Kogovšek, T.; Talaber, I., Malej, A. (2012) Plankton trends and community changes in a coastal sea: bottom-up vs. top-down control in relation to local-scale and large-scale drivers. Estuarine, Coastal and Shelf Science 115, 138148.

Muller-Karger, F, R. Varela, R, Thunell, R. Luerssen, C. Hu and J. Walsh. 2005) The importance of continental margins in the global carbon cycle. Geophys. Res. Letters, 32, DOI: 10.1029/2004GL021346

Muller-Karger, F., et al. (2013) The CARIACO Ocean Time-Series: 18 years of international collaboration in ocean biogeochemistry and ecological research, Ocean Carbon and Biogeochemistry Newsletter, Woods Hole Oceanographic Institution fall edition.

Mumby, P. J.; Hastings, A.; Edwards, H.J. (2007) Thresholds and the resilience of Caribbean coral reefs". Nature 450, 98-101. doi: $10.1038 /$ nature06252 PMID 17972885.

Naam, R., (2012) Arctic Sea ice: What, why and what next. Scientific American, http://blogs.scientificamerican.com/guest-blog/2012/09/21/arctic-sea-ice-whatwhy-and-what-next/

Naha Biswas,S., Godhantaraman, N., Sarangi, R.K., B.D. Bhattacharya, B.D., Sarkar, S.K., Satpathy, K.K. (2013) Bloom of the centric diatom Hemidiscus hardmannianus (Bacillariophyceae) and its impact on water quality characteristics and plankton community structure in Indian Sundarban mangrove wetlandCLEAN - Soil, Air and Water Pollution, 41 (4), 333-339.

Nam, S., Kim, H.-J., and Send, U. (2011) Amplification of hypoxic and acidic events by La Nina conditions on the continental shelf off California, Geophysical Research Letters 38, L22602.

Narváez, D., et al., (submitted) Long-term dynamics in Atlantic surfclam (Spisula Solidissima) populations: The role of bottom water temperature. J. Mar. Systems (this volume).

Ninčević Gladan, Ž., Marasović, I., Grbec, B., Skejić, S., Bužančić, M., Kušpilić, G., Matijević, S., Matić, F., (2010) Inter-decadal Variability in Phytoplankton Community in the Middle Adriatic (Kaštela Bay) in Relation to the North Atlantic Oscillation. Estuaries and Coasts 33, 376-383.

Nixon, S. W., and Buckley, B. A. (2002) "A strikingly rich zone"-nutrient enrichment and secondary production in coastal marine ecosystems, Estuaries 25, 782-796.

O'Brien, T.D. et al. (Ed.) (2012) ICES Phytoplankton and Microbial Plankton Status Report 2009/2010. ICES Cooperative Research Report, 313. ICES: Denmark. ISBN 978-87-7482-115-1. 196 pp

Paerl, H. W., Bales, J. D., Ausley, L. W., Buzzelli, C. P., Crowder, L. B., Eby, L. A., Fear, J. M., Go, M., Peierls, B. L., and Richardson, T. L. (2001) Ecosystem impacts of three sequential hurricanes (Dennis, Floyd, and Irene) on the United States' largest lagoonal estuary, Pamlico Sound, NC, Proceedings of the National Academy of Sciences 98, 5655-5660.

Paulmier, A., Ruiz-Pino, D., and Garçon, V. (2011) $\mathrm{CO}_{2}$ maximum in the oxygen minimum zone (OMZ), Biogeosciences 8, 239-252.

Phrampus, B. J., and Hornbach, M. J. (2012) Recent changes to the Gulf Stream causing widespread gas hydrate destabilization, Nature 490, 527-530. 
Pidgeon, N., and Fischhoff, B. (2011) The role of social and decision sciences in communicating uncertain climate risks, Nature Climate Change 1, 35-41.

Pätsch, J., Lenhart, H.-J. (2011) Daily nutrient loads of Nutrients, Total Alkalinity, Dissolved Inorganic Carbon and Dissolved Organic Carbon of the European continental rivers for the years 1977-2009. Berichte aus dem Zentrum fur Meeresund Klimaforschung, Reihe B: Ozeanographie, 50, Zentrum für Meeres- und Klimaforschung, Hamburg, 159 pp.

Prince, E. D., and Goodyear, C. P. (2006) Hypoxia-based habitat compression of tropical pelagic fishes, Fisheries Oceanography 15, 451-464.

Prince, E.D., Luo, J., Goodyear, C.P., Hoolihan, J.P., Snodgrass, D., Orbesen, E.S., Serafy, J.E., Ortiz, M., Schirripa, M.J. (2010) Ocean scale hypoxia-based habitat compression of Atlantic istiophorid billfishes. Fish. Oceanogr. 19, 448-462.

Rabalais, N. N. (2004), Eutrophication, in: The Global Coastal Ocean Multiscale Interdisciplinary Processes, edited by: Robinson, A. R., McCarthy, J., and Rothschild, B. J., The Sea, Vol. 13, Harvard University Press, 819-865, 2004.

Rabalais, N. N., R. J. Diaz, L. A. Levin, R. E. Turner, D. Gilbert and J. Zhang. (2010) Dynamics and distribution of natural and human-caused coastal hypoxia. Biogeosciences 7: 585-619.

Rabalais, N.N., W.-J. Cai, J. Carstensen, D.J. Conley, B. Fry, X. Hu, Z. Quiñones-Rivera, R. Rosenberg, C.P. Slomp, R.E. Turner, M. Voss, B. Wissel, and J. Zhang. 2014. Eutrophication-driven deoxygenation in the coastal ocean. Oceanography 27(1):172-183, http://dx.doi.org/10.5670/oceanog.2014.21.

Rabouille, C., Conley, D.J., Dai, M.H., Cai, W.J., Chen, C.T.A., Lansard, B., Green, R., Yin, K., Harrison, P.J., Dagg, M., McKee, B., (2008). Comparison of hypoxia among four river-dominated ocean margins: The Changjiang (Yangtze), Mississippi, Pearl, and Rhone rivers. Continental Shelf Research 28, 1527-1537.

Rabouille, O., O. Radakovitch, C. Estournel, X. Durrieu de Maron, C. Guieu, and R. Sempere. (2013) The Fate of Rhone River carbon on the mediterranean continental margin, its export to the open sea and its relation to climatic parameters. Oral Presentation, IMBER IMBIZO, Jan. 2013, Goa, India.

Ragueneau, O., Chauvaud, L., Moriceau, B., Leynaert, A., Thouzeau, G., Donval, A., Le Loc'h, F. and Jean, F., (2005) Biodeposition by an invasive suspension feeder impacts the biogeochemical cycle of $\mathrm{Si}$ in a coastal ecosystem (Bay of Brest, France). Biogeochemistry, DOI 10.1007/s10533-004-5677-3.

Ragueneau, O., Conley, D.J., Ni Longphuirt, S., Slomp, C. et Leynaert, A., (2006) A review of the Si biogeochemical cycle in coastal waters, II: anthropogenic perturbation of the Si cycle and responses of coastal ecosystems. Dans: LandOcean nutrient fluxes: silica cycle. Ittekkot, V., Humborg, C., Garnier, J. (Eds.), SCOPE Book, Island Press, pp. 197-213.

Raimonet,M., Ragueneau, O, Jacques, V. Corvaisier, R, Moriceau, B., Khripounoff, A., Rabouille, C. (submitted) Rapid transport and high accumulation of riverine $\mathrm{Si}$ in the Congo deep sea fan (this volume).

Reid,W. V., Chen,D., Goldfarb,L., Hackmann, H., Lee,Y. T.,Mokhele,K.,Ostrom, E., Raivio, K.,Rockström, J.,Schellnhuber, H. J., Whyte,A. (2010) Earth System Science for Global Sustainability: Grand Challenges. Science 330, 916-917. 
Ribera d'Alcalà, M., Conversano, F., Corato, F., Licandro, P., Mangoni, O., Marino, D., Mazzocchi, M. G., Modigh, M., Montresor, M., Nardella, M., Saggiomo, V., Sarno, D., Zingone, A. (2004) Seasonal patterns in planktonic communities in a pluriannual time series at a coastal Meditrranean site (Gulf of Naples): an attempt to discern recurrences and trends, Scientia Marina, 68(Suppl.1), 65-83,

Robbins LL, Wynn JG, Lisle JT, Yates KK, Knorr PO, et al. (2013) Baseline monitoring of the Western Arctic Ocean estimates 20\% of Canadian Basin surface waters Are undersaturated with respect to aragonite. PLOS ONE 8(9), e73796. doi:10.1371/journal.pone.0073796

Sattar, M.A., C.Kroeze, and M. STrokal. 2014. The increasing impact of food production on nutrient export by rivers to the Bay of Bengal 1970-2050. Mar. Poll. Bull. 80: $168-178$.

Schuur, E.A.G., (2013) High risk of permafrost thaw. Lawrence Berkeley National Laboratory. http://dx.doi.org/doi: 10.1038/480032a

Send, U., and Nam, S. (2012) Relaxation from upwelling: The effect on dissolved oxygen on the continental shelf, Journal of Geophysical Research: Oceans (1978, Äi2012) 117.

Soetaert, K., Middelburg, J.J., Heip, C., Meire, P., Van Damme, S., Maris, T., (2006) Long-term change in dissolved inorganic nutrients in the heterotrophic Scheldt estuary (Belgium, The Netherlands). Limnology and Oceanography 51 (1, Part 2), 409e423.

Srinivas, B., Sarin, M.M. and Sarma, S.S.V.V. (submitted) Atmospheric outflow of nutrients to the Bay of Bengal: Impact of continental sources. Journal of Marine Systems (this volume)

Stramma, L., Prince, E. D., Schmidtko, S., Luo, J., Hoolihan, J. P., Visbeck, M., Wallace, D. W., Brandt, P., and Kortzinger, A. (2011) Expansion of oxygen minimum zones may reduce available habitat for tropical pelagic fishes, Nature Climate Change 2, 33-37.

Stramma, L., Schmidtko, S., Levin, L. A., and Johnson, G. C. (2010) Ocean oxygen minima expansions and their biological impacts, Deep Sea Research Part I: Oceanographic Research Papers 57, 587-595.

Swaney, D. P., Hong, B., Selvam, P., Howarth, R.W., Ramesh, R., Ramachandran, P., (2013) Net anthropogenic nitrogen inputs and nitrogen fluxes from Indian watersheds: a preliminary assessment, Journal of Marine Systems, submitted.

Swaney, D. P., Hong, B., Ti, C., Howarth, R. W., and Humborg, C. (2012) Net anthropogenic nitrogen inputs to watersheds and riverine $\mathrm{N}$ export to coastal waters: a brief overview, Current Opinion in Environmental Sustainability 4, 203211.

Taylor, G.T., Muller-Karger, F.E., Thunell, R.C., Scranton, M.I., Astor, Y., Varela, R., Ghinaglia, L.T., Lorenzoni, L., Fanning, K.A., Hameed, S., Doherty, O., (2012) Ecosystem responses in the southern Caribbean Sea to global climate change. P. Natl. A. Sci. USA, doi:10.1073/pnas.1207514109

Thomas, P., Rahman, M. S., Kummer, J. A., and Lawson, S. (2006) Reproductive endocrine dysfunction in Atlantic croaker exposed to hypoxia, Marine environmental research 62, S249-S252. 
Thomsen, J., Gutowska, M., Saphorster, J., Heinemann, A., Trubenbach, K., Fietzke, J., Hiebenthal, C., Eisenhauer, A., Kortzinger, A., and Wahl, M. (2010) Calcifying invertebrates succeed in a naturally $\mathrm{CO} 2$-rich coastal habitat but are threatened by high levels of future acidification, Biogeosciences 7, 3879-3891.

Trenberth, K.E., Jones, P.D., Ambenje, P., Bojariu, R., Easterling, D., Klein Tank, A., Parker, D., Rahimzadeh, F., Renwick, J. A., Rusticucci, M., Soden, B., Zhai, P., (2007) Observations: Surface and Atmospheric Climate Change. In: Climate Change 2007: The Physical Science Basis. Contribution of Working Group I to the Fourth Assessment Report of the Intergovernmental Panel on Climate Change [eds Solomon, S., Qin, D., Manning, M., Chen, Z., Marquis, M., Averyt, K.B., Tignor, M., Miller, H.I.]. Cambridge University Press, Cambridge, United Kingdom and New York, NY, USA.

Waldbusser, G.G., E.N. Powell and R. Mann. (2013) Ecosystem effects of shell aggregatioins and cycling in coastal waters: an example of Chesapeake Bay oyster reefs. Ecology 94, 895-903.

Walsh, J. J., Biscaye, P. E., and Csanady, G. T. (1988) The 1983-1984 shelf edge exchange processes (SEEP)-I experiment: hypotheses and highlights, Continental Shelf Research 8, 435-456.

Wassmann, P. (2011) Arctic Marine ecosystems in an era of rapid climate change. Progress in Oceanography 90: 1-17.

Wassmann, P., Lenton, T., (2012) Arctic tipping points in the Earth System perspective. AMBIO 41(1), 1-9.

Weinberg, J. (2005) Bathymetric shift in the distribution of Atlantic surfclams: response to warmer ocean temperature. ICES Journal of Marine Science, 62: 1444-1453.

Whiteman, G., Hope, C., Wadhams, P., (2013) Vast costs of Arctic change. Nature, 499: 401- 403, doi:10.1038/499401a.

Wiltshire, K. H., Malzahn, A. M., Wirtz, K., Greve, W., Janisch, S., Mangelsdorf, P., Manly, B. F., Boersma, M. (2008) Resilience of North Sea phytoplankton spring bloom dynamics: An analysis of long-term data at Helgoland Roads. Limnology and Oceanography 54(4), 1294-1302.

Wishner, K.F., Outram, D. M., Seibel, B. A., Daly, K., and Williams, R. L. (2013) Zooplankton in the Eastern Tropical North Pacific: Boundary effects of oxygen minimum zone expansion. Deep-Sea Research I 79, 122-140.

Wooster, W. S., and Zhang, C. I. (2004) Regime shifts in the North Pacific: early indications of the 1976-1977 event, Progress in Oceanography 60, 183-200.

World Resources Institute, (2013) Interactive map of eutrophication \& hypoxia. Available online: http://www.wri.org/resource/interactive-map-eutrophicationhypoxia (accessed 1 January, 2014).

Yan, W.J., Mayorga, E., Li, X.Y., Seitzinger, S.P., Bouwman, A.F., (2010) Increasing anthropogenic nitrogen inputs and riverine DIN exports from the Changiiang River basin under changing human pressures. Global Biogeochemical Cycles, 24 Gb0a06, doi: 10.1029/2009gb003575.

Yasuhara, M., Hunt, G., Breitburg, D., Tsujimoto, A., and Katsuki, K. (2012) Humaninduced marine ecological degradation: micropaleontological perspectives, Ecology and Evolution 2, 3242-3268. 
Yu, P. C., Matson, P. G., Martz, T. R., and Hofmann, G. E. (2011) The ocean acidification seascape and its relationship to the performance of calcifying marine invertebrates: Laboratory experiments on the development of urchin larvae framed by environmentally-relevant $\mathrm{pCO} 2 / \mathrm{pH}$, Journal of Experimental Marine Biology and Ecology 400, 288-295.

Zhai, W.-D., Zheng, N., Huo, C., Xu, Y., Zhao, H.-D., Li, Y.-W., Zang, K.-P., Wang, J.Y., and Xu, X.-M. (2013) Subsurface low pH and carbonate saturation state of aragonite on China side of the North Yellow Sea: combined effects of global atmospheric $\mathrm{CO} 2$ increase, regional environmental changes, and local biogeochemical processes, Biogeosciences Discussions 10, 3079-3120.

Zhai, W.D., Dai, M.H., Chen, B.S., Guo, X.H., Li, Q., Shang, S.L., Zhang, C.Y., Cai, W.J., Wang, D.X., 2013b. Seasonal variations of sea-air CO2 fluxes in the largest tropical marginal sea (South China Sea) based on multiple-year underway measurements. Biogeosciences, 10(11): 7775-7791

Zhang, C. I., and Gong, Y. (2005) Effect of ocean climate changes on the Korean stock of Pacific saury, Cololabis saira (Brevoort), Journal of Oceanography 61, 313-325.

Zhang, J., Yu, Z., Raabe, T., Liu, S., Starke, A., Zou, L., Gao, H., and Brockmann, U. (2004) Dynamics of inorganic nutrient species in the Bohai seawaters, Journal of Marine Systems 44, 189-212.

Zhu, Z.-Y., Zhang, J., Wu, Y., Zhang, Y.-Y., Lin, J., Liu, S.-M., (2011) Hypoxia off the Changjiang (Yangtze River) Estuary: Oxygen depletion and organic matter decomposition. Marine Chemistry 125, 108-116.

Zillén, L., D.J. Conley, T.Andren, E. Andren, S. Bjorck (2008) Past occurrences of hypoxia in the Baltic Sea and the role of climate variability, environmental change and human impact. Earth-Science Reviews 91, 77-92.

Zingone, A., Dubroca, L., Iudicone, D., Margiotta, F., Corato, F., Ribera d'Alcalà, M., Saggiomo, V., Sarno, D., (2010) Coastal phytoplankton do not rest in winter. Estuaries and Coasts 33, 342-361. 
Table 1. Environmental drivers and ecosystem responses on continental margins: Case studies

\begin{tabular}{|c|c|c|c|c|c|c|c|c|c|c|c|}
\hline \multirow{2}{*}{\begin{tabular}{|c|}
$\begin{array}{c}\text { Consequences \& } \\
\text { regional } \\
\text { responses }\end{array}$ \\
(Supplements*)
\end{tabular}} & \multicolumn{10}{|c|}{ Drivers of environmental change on continental margins from regional to global scale } & \multirow[b]{2}{*}{ Actions taken } \\
\hline & $\begin{array}{l}\text { Land use } \\
\text { change }\end{array}$ & $\begin{array}{l}\text { Damming, diking, } \\
\text { water diversion }\end{array}$ & Alien species & $\begin{array}{c}\text { Anthropogenic nutrients \& } \\
\text { pollutants }\end{array}$ & $\begin{array}{c}\text { Energy \& } \\
\text { mineral } \\
\text { extractions } \\
\text { from the sea }\end{array}$ & Overfishing & $\begin{array}{l}\text { Changes in } \\
\text { water cycle }\end{array}$ & $\begin{array}{l}\text { Rising sea } \\
\text { level }\end{array}$ & Warming & Climate change \& oscillation & \\
\hline $\begin{array}{l}\text { General } \\
\text { consequences }\end{array}$ & $\begin{array}{l}\text { Changes in soil } \\
\text { qual. \& erosion } \\
\text { in watershed }\end{array}$ & $\begin{array}{l}\text { Sed. retention, decr. } \\
\text { runoff }\end{array}$ & $\begin{array}{l}\text { Change in } \\
\text { ecosystem } \\
\text { structure }\end{array}$ & $\begin{array}{l}\text { Eutrophication, change in } \\
\text { nutrient ratios \& plankton } \\
\text { community, } \mathrm{HAB} \text {, hypoxia }\end{array}$ & $\begin{array}{l}\text { Change in } \\
\text { seascape \& } \\
\text { marine } \\
\text { environments }\end{array}$ & $\begin{array}{l}\text { Decr. fish stock, } \\
\text { trophic } \\
\text { cascades }\end{array}$ & $\begin{array}{l}\text { Extreme } \\
\text { weather, } \\
\text { flooding, } \\
\text { drought }\end{array}$ & $\begin{array}{l}\text { Lowland } \\
\text { flooding, salt } \\
\text { water intrusion }\end{array}$ & \begin{tabular}{|l|} 
Incr. \\
stratification, \\
drop in $\mathrm{O}_{2}$, incr. \\
vulnerability \\
\end{tabular} & $\begin{array}{l}\text { Change in ocean circulation, } \\
\text { upwelling, }\end{array}$ & \\
\hline \multicolumn{12}{|c|}{ American margins } \\
\hline $\begin{array}{l}\text { Cariaco Basin } \\
\text { (B1) }\end{array}$ & & & & & & $\begin{array}{l}\text { Collapse of } \\
\text { Spanish sardine } \\
\text { (Sardinella } \\
\text { aurita) }\end{array}$ & $\begin{array}{l}\text { Freshening of } \\
\text { surface waters } \\
\text { due to higher } \\
\text { regional } \\
\text { precipitation }\end{array}$ & & $\begin{array}{l}>1^{1} \mathrm{C} \text { incr. since } \\
1995\end{array}$ & $\begin{array}{l}\text { Decr. upwelling, PP and } \\
\text { phytoplankton biomass; incr. } \\
\mathrm{N}^{*} \text {., change in ecosystem } \\
\text { structure; Increasing zooplankton } \\
\text { biomass }\end{array}$ & \\
\hline $\begin{array}{l}\text { Chesapeake Bay } \\
\text { (B2) }\end{array}$ & $\begin{array}{l}\text { Degrading } \\
\text { water qual. \& } \\
\text { clarity }\end{array}$ & $\begin{array}{l}\text { Blocked migratory } \\
\text { pathways for } \\
\text { anadromous fish }\end{array}$ & \begin{tabular}{|l|} 
Decreased \\
oyster \\
populations and \\
increased \\
piscivory \\
\end{tabular} & $\begin{array}{l}\text { Seasonal hypoxia, decline } \\
\text { of SAV, fish advisories }\end{array}$ & & $\begin{array}{l}\text { extirpation of } \\
\text { sturgeon, } \\
\text { collapse of } \\
\text { oyster fishery }\end{array}$ & $\begin{array}{l}\text { Salinity drop } \\
\text { following } \\
\text { Tropical Storm } \\
\text { Agnes }\end{array}$ & $\begin{array}{l}\text { Rate of sea } \\
\text { level rise much } \\
\text { higher than } \\
\text { average }\end{array}$ & & Change in water exchange rate & $\begin{array}{l}\text { Acts for reducing } \\
\text { nutrients \& } \\
\text { restoring SAV, } \\
\text { oysters; removing } \\
\text { blockages to fish } \\
\end{array}$ \\
\hline $\begin{array}{l}\text { San Francisco } \\
\text { Bay } \\
\text { (B3) }\end{array}$ & & $\begin{array}{l}\text { Decreased sediment } \\
\text { supply, shrinking } \\
\text { mudflats, incr. } \\
\text { salinity }\end{array}$ & $\begin{array}{l}\text { Decreased } \\
\text { phytopl. PP due } \\
\text { to Asian clams }\end{array}$ & Degrading water quality & & & $\begin{array}{l}\text { Drought and } \\
\text { water diversion } \\
\text { trigger invasion }\end{array}$ & & & Change in bio-community & $\begin{array}{l}1972 \text { Clean Water } \\
\text { Act }\end{array}$ \\
\hline \multicolumn{12}{|c|}{ Asian margins } \\
\hline (B4) & $\begin{array}{l}\text { Changes in tidal } \\
\text { regime }\end{array}$ & \begin{tabular}{|l|} 
Massive drop in \\
water discharge and \\
sediment load, \\
fishery collapse in \\
1990s
\end{tabular} & & $\begin{array}{l}\text { High } \mathrm{N} \text {, low } \mathrm{P} \text { and } \mathrm{Si} \text {, } \\
\text { decrease in diatom/ } \\
\text { dinoflagellate ratio }\end{array}$ & & $\begin{array}{l}\text { Decrease in fish } \\
\text { biomass; } \\
\text { dominant fish } \\
\text { species } \\
\text { changed from } \\
\text { bottom to } \\
\text { pelagic fish }\end{array}$ & & & $\begin{array}{l}0.0110 \mathrm{C} \text { per } \\
\text { year increase } \\
\text { during the } \\
1960 \mathrm{~s}-1990 \mathrm{~s}\end{array}$ & & $\begin{array}{l}\text { Artificially controlled } \\
\text { water discharge in } \\
\text { Yellow River }\end{array}$ \\
\hline \multicolumn{12}{|l|}{ European margins } \\
\hline $\begin{array}{l}\text { Mediterranean - } \\
\text { N. Adriatic Sea } \\
\text { (B5) }\end{array}$ & & & & $\begin{array}{l}\text { N/P increase, anoxic events } \\
\text { (1970s-1980s), loss of } \\
\text { macrobenthos; trend } \\
\text { reversed recently. }\end{array}$ & & $\begin{array}{l}\text { Loss of } \\
\text { demersal fish, } \\
\text { small pelagic } \\
\text { fish and top } \\
\text { predators }\end{array}$ & & $\begin{array}{l}\text { Reduced river } \\
\text { flow, salinity rise }\end{array}$ & & & $\begin{array}{l}\text { Mandates of } \\
\text { reduction in P } \\
\text { loading }\end{array}$ \\
\hline $\begin{array}{l}\text { North Sea } \\
\text { (B6) }\end{array}$ & & Altered mudflat & & $\begin{array}{l}\text { Massive coastal } \\
\text { environment deterioration in } \\
\text { 1980s }\end{array}$ & $\begin{array}{l}\text { Massive wind } \\
\text { farming } \\
34\end{array}$ & & & & \begin{tabular}{|l|} 
Temporally and \\
regionally faster \\
than global \\
mean, provoked \\
ecosystem shift
\end{tabular} & $\begin{array}{l}\text { NAO state determines circulation } \\
\text { mode and nutrient inventories }\end{array}$ & $\begin{array}{l}\text { EU wide mitigation, } \\
\text { Marine Strategy } \\
\text { Framework } \\
\text { Directive }\end{array}$ \\
\hline
\end{tabular}

*Note: More descriptions and references about the case studies are presented in electronic supplements listed under each case heading.

Increase in $\mathrm{N}^{*}$. Whether this is due to increased $\mathrm{N}$ fixation is being explored 
Table 2. The temporal trends of the environmental variables presented in Fig. 3. All trends are statistically significant except those shown in italics. (For more detailed 1493 information on the linear regressions see Supplement A.)

1494

\begin{tabular}{|l|l|l|l|l|l|l|l|}
\hline Site & $\begin{array}{l}\mathrm{SST} \\
\left({ }^{\circ} \mathrm{C} \mathrm{yr}-1\right)\end{array}$ & $\begin{array}{l}\mathrm{SSS} \\
\left(\mathrm{yr}^{-1}\right)\end{array}$ & $\begin{array}{l}\mathrm{Q} \\
\left(\mathrm{km}^{3} \mathrm{yr}^{-1}\right)\end{array}$ & $\begin{array}{l}\mathrm{DIN} \\
\left(\mathrm{Kt} \mathrm{yr}^{-1}\right)\end{array}$ & $\begin{array}{l}\mathrm{DIP} \\
\left(\mathrm{Kt} \mathrm{yr}^{-1}\right)\end{array}$ & $\begin{array}{l}\mathrm{Chl} \\
\left(\mathrm{mg} \mathrm{m}^{-3}\right. \\
\left.\mathrm{yr}^{-1}\right)\end{array}$ & $\begin{array}{l}\mathrm{O}_{2} \\
\text { saturation } \\
\left(\% \mathrm{yr}^{-1}\right)\end{array}$ \\
\hline $\begin{array}{l}\text { Bohai Sea } \\
\text { Basin }\end{array}$ & 0.0022 & 0.0632 & $-0.75^{(1)}$ & & & & \\
\hline $\begin{array}{l}\text { East China } \\
\text { Sea }\end{array}$ & 0.0282 & & 3.34 & 26.1 & & 0.0135 & -0.536 \\
\hline North Sea & $0.0376^{(2)}$ & 0.0007 & -7.44 & -12.1 & -2.3 & & \\
\hline SF Bay & $-0.0290^{(3)}$ & 0.0427 & & & & 0.131 & $-0.290^{(3)}$ \\
\hline
\end{tabular}

Notes: (1) Water discharge of the Yellow River that empties into the Bohai Sea. (2) The 1498 mean temperature of the top $10 \mathrm{~m}$ in the North Sea in winter months (DJF). (3) The bottom temperature of the USGS Station 18 in the San Francisco Bay. 


\section{Figure Captions}

Figure 1. Map showing locations of time-series observations that exemplify the interplay of natural variability, $\mathrm{CO}_{2}$-driven climate change and human activities to shape margin ecosystems. Each area is discussed in the manuscript or summarized in Table 1. 1. Arctic Sea; American margins: 2. Cariaco Basin, 3. Chesapeake Bay, 4. Gulf of Mexico off Louisiana, 5. San Francisco Bay, 6. Southern California Bight; African margins: 7. Canary Current System, 8. Congo River Submarine Canyon; Asian seas: 9. Bay of Bengal, 10. Bohai Sea, 11. East China Sea; European seas: 12. Baltic Sea, 13. Black Sea, 14. Mediterranean - Corsica (Liguran Sea), 15. Mediterranean - N. Adriatic Sea, 16. North Sea.

Figure 2. Data plots of $\mathrm{O}_{2}$ and $\mathrm{pH}$ illustrating time scales of natural hydrographic variability in the nearshore southern California Bight, USA. (a) Decadal scale suggesting regime shifts (modified from McClatchie et al., 2010). (b) Interannual scale illustrating effects of ENSO at a site $6 \mathrm{~km}$ from Del Mar (from Nam et al., 2011) (c) Seasonal scale combining CalCOFI data at line 93 and continuous mooring measurements (from Send and Nam, 2012), (d) Event (week) scale illustrating upwelling (blue) and relaxation (green) phases (modified from Send and Nam, 2012), (e) semi-diurnal and diurnal scale variations in the La Jolla Kelp Forest during upwelling phase (blue) when there are strong semidiurnal signals and relaxation phase (green) when kelp influences the oxygen and $\mathrm{pH}$ variability (Frieder et al., unpublished).

Figure 3. Time series of sea surface temperature (SST) (a), sea surface salinity (SSS) (b), nutrient loads (c), riverine discharge (d), chlorophyll- $a$ (e), and saturation of dissolved oxygen (f) from the Cariaco Basin and San Francisco Bay (SF Bay) in the Americas, the East China Sea (ECS) and Bohai Sea (BH) in Asia, and the North Sea (NS) in Europe (See Fig. 1 for location of time-series stations). SST time series include values obtained from satellite remote sensing monthly composites (lines without symbols) from NOAA's National Climatic Data Center (See Supplement A), and in situ observations (lines with symbols). Statistically significant regression $(p<0.1)$ results are shown as solid straight lines; insignificant ones are shown as dashed lines. (See text).

Figure 4. The relationship between nitrogen loading and fisheries landings as a function of hypoxic area for mobile species in estuaries and semi-enclosed seas. Modified from Breitburg et al., 2009b. 
1540 Figure 1

1541

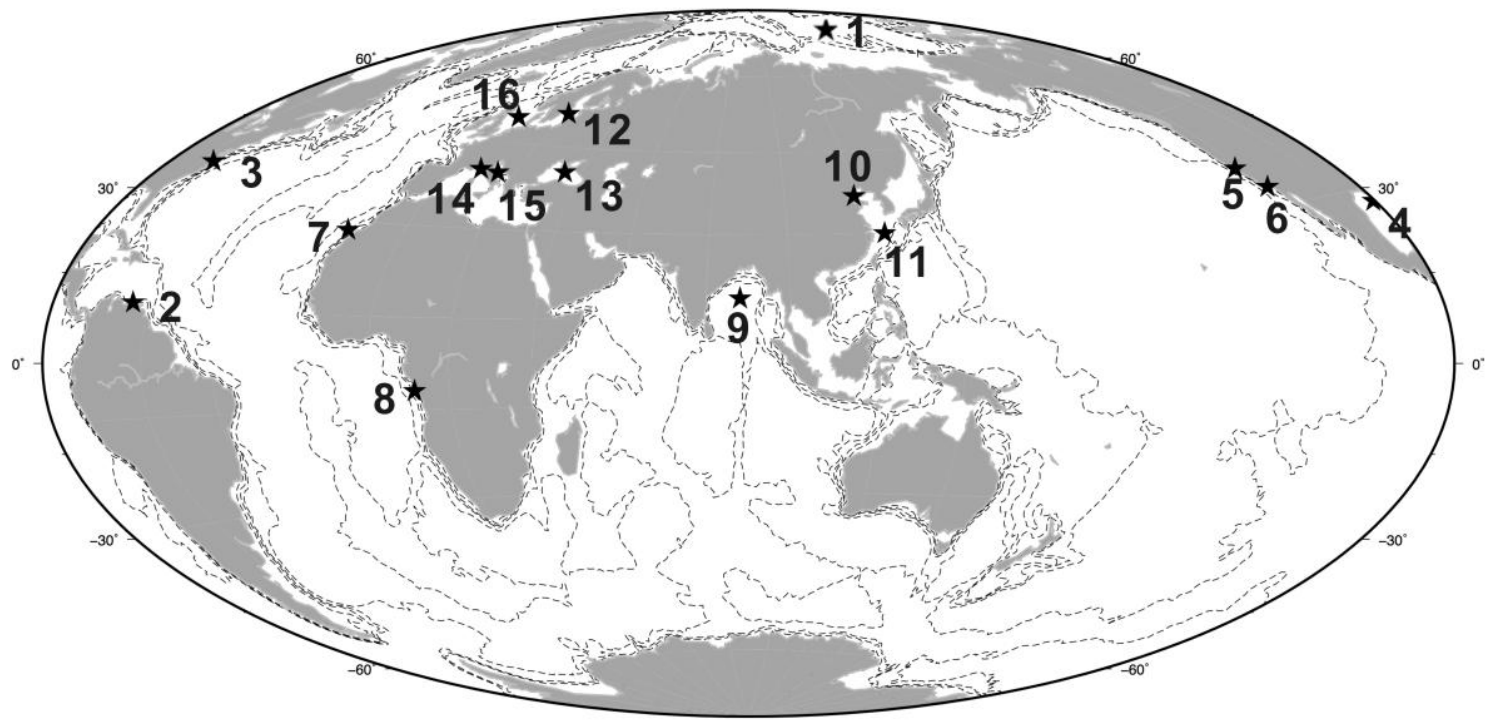

1542

1543 
Figure 2

a) REGIME SCALE

(decadal)

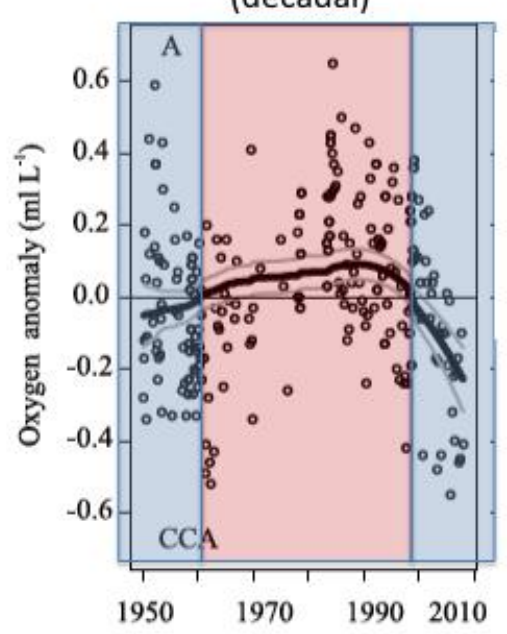

e) SEMIDIURNAL DIEL

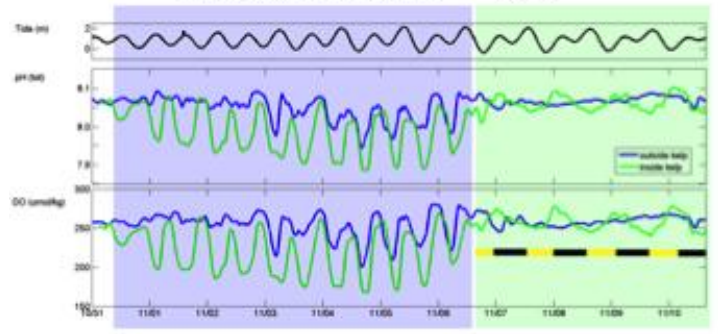

b) ENSO (interannual)
2009-2010 2010-2011

El Nino La Nina

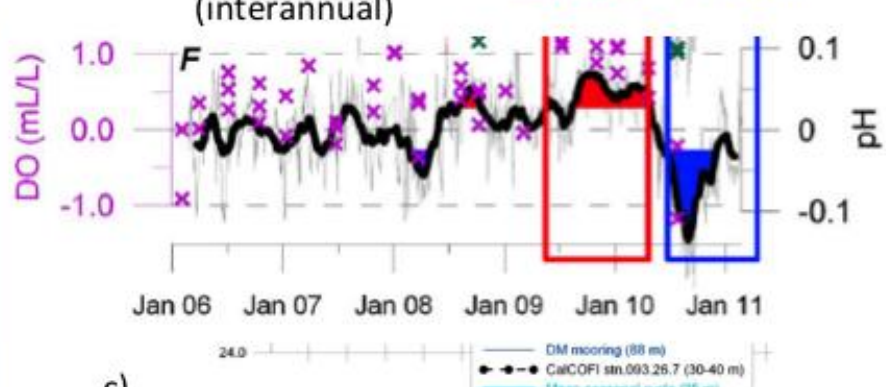

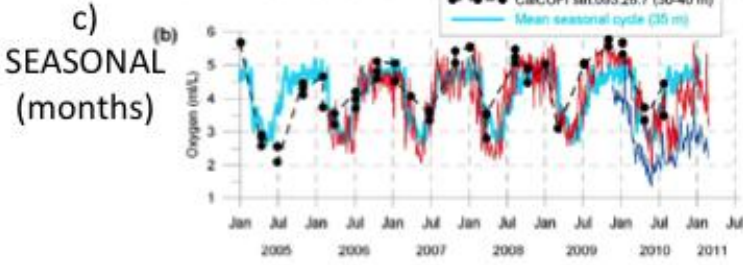

1548

1549

1550

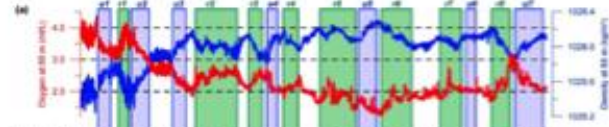

d) EVENTSCALE (weeks)

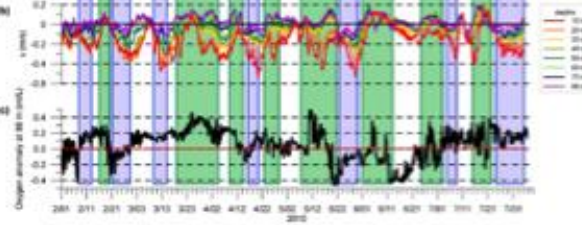


Figure 3.
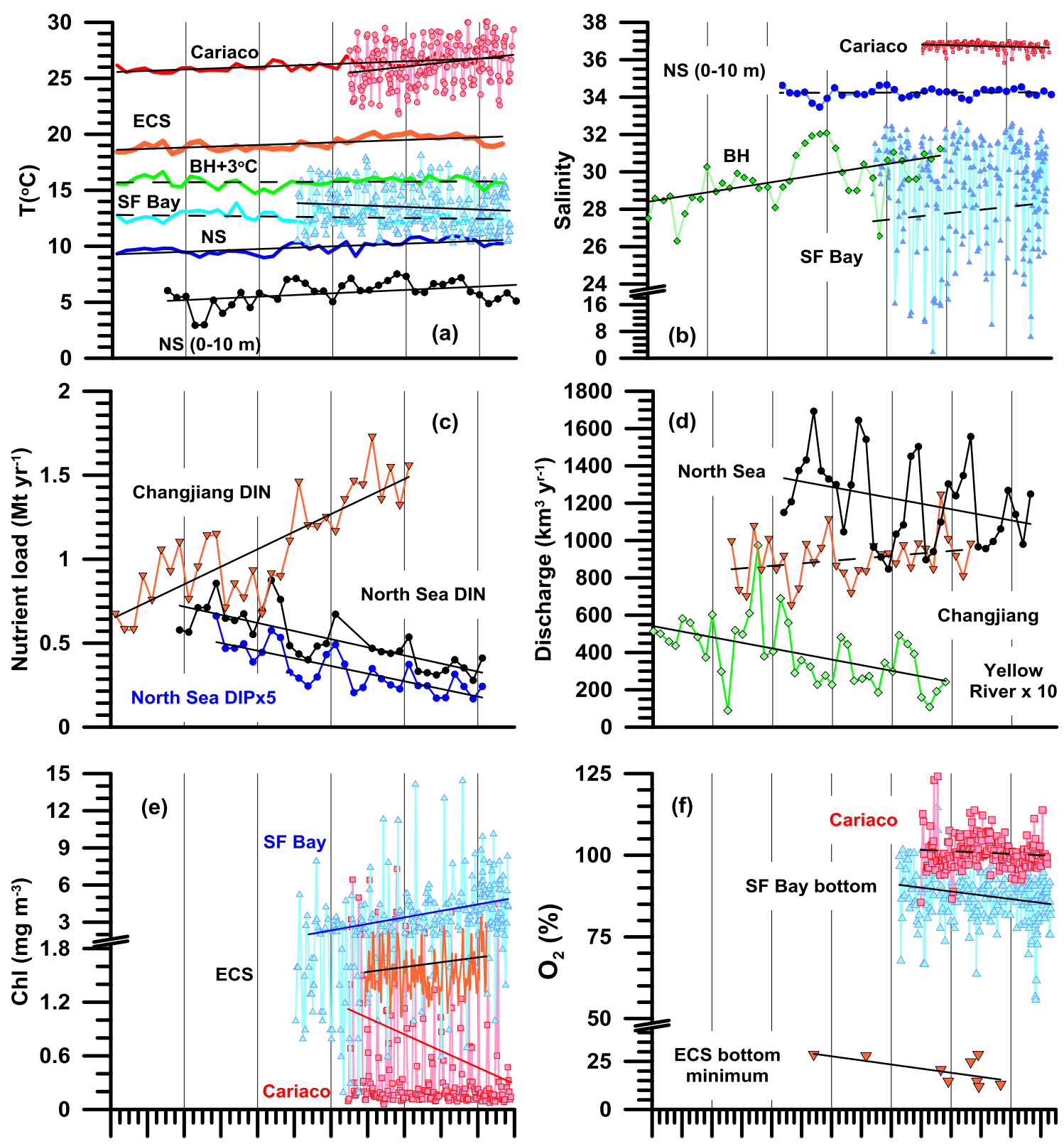
$1554 \quad$ Figure 4.

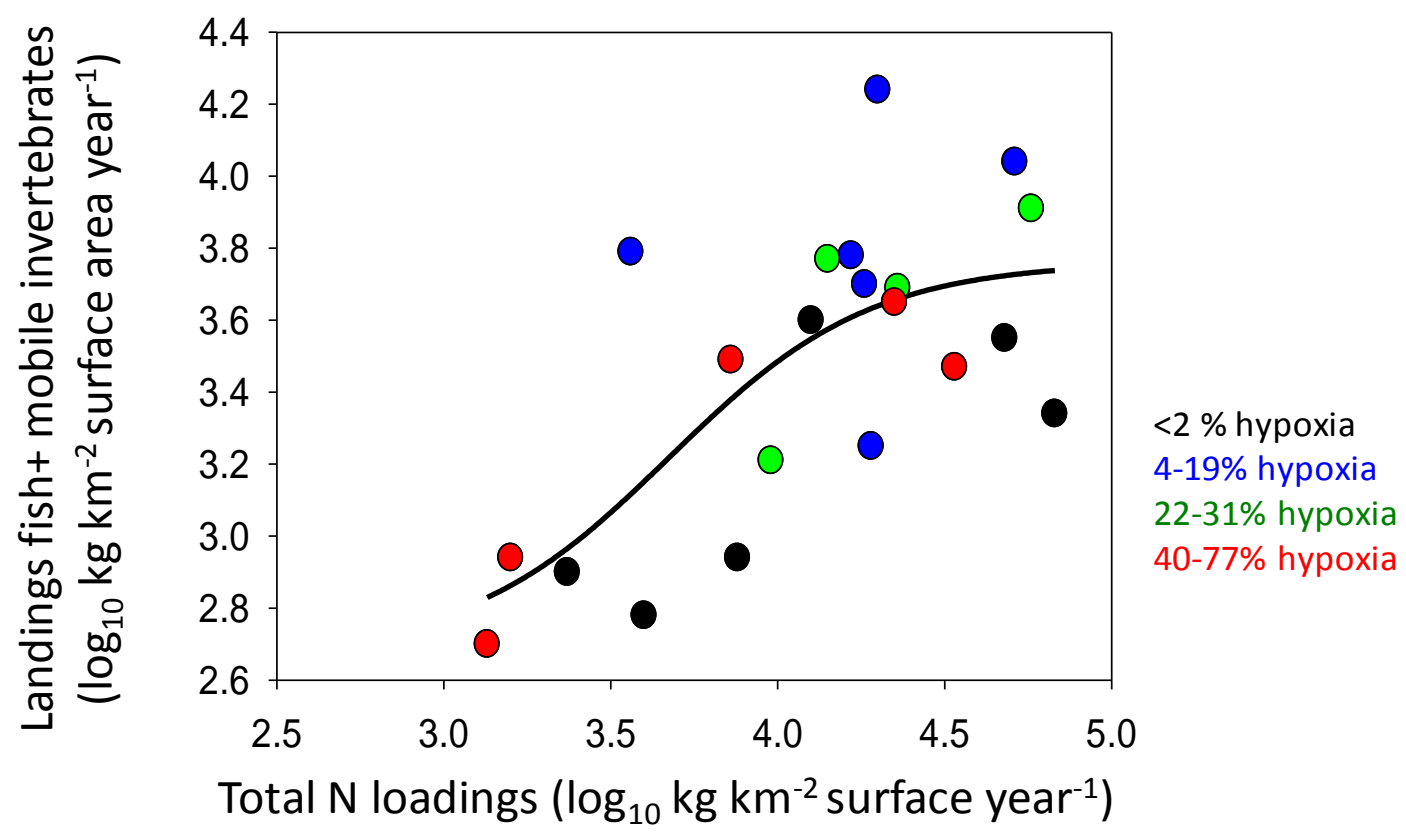

1555

1556

1557 
1642 Table A1. Locations of margin time series observations and data sources.

\begin{tabular}{|c|c|c|c|}
\hline Sites & Coordinates & Data sources & Remarks \\
\hline Bohai Sea & $\begin{array}{l}37-41^{\circ} \mathrm{N}, 117- \\
121^{\circ} \mathrm{E}\end{array}$ & $\begin{array}{l}\text { SSS: Lin et al. (2001) } \\
\text { Discharge: Liu et al. (2012); } \\
\text { Liu (this issue) }\end{array}$ & $\begin{array}{l}\text { Domain for satellite SST } \\
\text { data retrieval }\end{array}$ \\
\hline Cariaco Basin & $\begin{array}{l}10.2-11.0^{\circ} \mathrm{N},- \\
64 \sim 66^{\circ} \mathrm{W}\end{array}$ & SST: See text & $\begin{array}{l}\text { Domain for satellite SST } \\
\text { data retrieval }\end{array}$ \\
\hline $\begin{array}{l}\text { CARIACO } \\
\text { Sta }\end{array}$ & $\begin{array}{l}10^{\circ} 30^{\prime} \mathrm{N} 64^{\circ} \\
40^{\prime} \mathrm{W}\end{array}$ & $\begin{array}{l}\text { (http://imars.marine.usf.edu/car } \\
\text { iaco/cariaco-ocean-time-series- } \\
\text { program) }\end{array}$ & In situ observations \\
\hline $\begin{array}{l}\text { East China } \\
\text { Sea }\end{array}$ & $\begin{array}{l}28-32^{\circ} \mathrm{N}, 121- \\
125^{\circ} \mathrm{E}\end{array}$ & $\begin{array}{l}\text { SST: See text } \\
\text { Discharge, DIN load: Liu et al. } \\
\text { (this issue) }\end{array}$ & $\begin{array}{l}\text { Domain for satellite SST } \\
\text { data retrieval }\end{array}$ \\
\hline North Sea & $\begin{array}{l}53 \sim 57^{\circ} \mathrm{N} \\
4 \sim 8.6^{\circ} \mathrm{E}\end{array}$ & $\begin{array}{l}\text { SST, SSS: } \\
\text { (http://www.ices.dk/marine- } \\
\text { data/dataset- } \\
\text { collections/Pages/default.aspx) } \\
\text { accessed on March 31, 2014 } \\
\text { Discharge, nutrient loads: } \\
\text { Pätsch and Lenhart (2011) }\end{array}$ & ICES data \\
\hline North Sea (L) & $\begin{array}{l}53-59^{\circ} \mathrm{N},- \\
2 \sim 8^{\circ} \mathrm{N}\end{array}$ & SST: See text & $\begin{array}{l}\text { Larger domain for satellite } \\
\text { SST data retrieval }\end{array}$ \\
\hline $\begin{array}{l}\text { San } \\
\text { Francisco } \\
\text { Bay }\end{array}$ & $\begin{array}{l}38^{\circ} 50.8^{\prime} \mathrm{N} \\
121^{\circ} 25.3^{\prime} \mathrm{W}\end{array}$ & 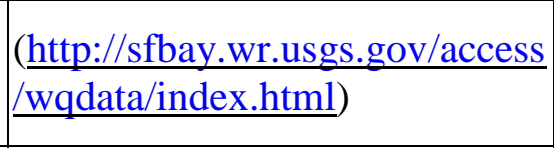 & $\begin{array}{l}\text { USGS Sta } 18 \text { (Point } \\
\text { Blunt) } \\
\text { Water depth }=43.0\end{array}$ \\
\hline \begin{tabular}{l|} 
Coastal zone \\
adjacent to \\
SF Bay
\end{tabular} & \begin{tabular}{|l}
$36.2-38.1^{\circ} \mathrm{N}$, \\
$122.5^{-}$ \\
$124.7^{\circ} \mathrm{W}$ \\
\end{tabular} & SST: See text & $\begin{array}{l}\text { Domain for satellite SST } \\
\text { data retrieval }\end{array}$ \\
\hline
\end{tabular}


1646 Table A2. Results of linear regression analysis of margin time series data. The 1647 statistically insignificant trends, defined as those with $p>0.1$, are shown in italics.

\begin{tabular}{|c|c|c|c|c|c|c|}
\hline Variables & Site & Period & $\begin{array}{l}\text { Trend } \\
\text { (per year) }\end{array}$ & $\mathrm{n}$ & $\mathrm{R}^{2}$ & $p$ \\
\hline \multirow{10}{*}{$\operatorname{SST}\left({ }^{\circ} \mathrm{C}\right)$} & Bohai Sea & $1970-2012$ & 0.0022 & 43 & 0.004 & 0.6830 \\
\hline & Cariaco Basin & $1970-2012$ & 0.0303 & 43 & 0.548 & $<0.001$ \\
\hline & Cariaco Basin & $1995-2012$ & 0.0351 & 18 & 0.168 & 0.0917 \\
\hline & CARIACO Sta & $1995-2013$ & 0.0895 & 198 & 0.058 & $<0.001$ \\
\hline & East China Sea & 1970-2012 & 0.0282 & 43 & 0.438 & $<0.001$ \\
\hline & \begin{tabular}{|l|}
$\begin{array}{l}\text { North Sea } \\
\text { (winter) }\end{array}$ \\
\end{tabular} & $1976-2013$ & 0.0376 & 38 & 0.160 & 0.0129 \\
\hline & North Sea (L) & $1970-2012$ & 0.0301 & 43 & 0.493 & $<0.001$ \\
\hline & SF Bay & $1990-2013$ & -0.0126 & 288 & 0.002 & 0.498 \\
\hline & Adj. SF Bay & $1970-2012$ & -0.0087 & 43 & 0.053 & 0.138 \\
\hline & $\begin{array}{l}\text { SF Bay bottom } \\
\text { water }\end{array}$ & 1990-2013 & -0.0290 & 285 & 0.011 & 0.071 \\
\hline \multirow{4}{*}{ SSS } & CARIACO Sta & $1995-2013$ & -0.0097 & 188 & 0.048 & 0.0025 \\
\hline & $\begin{array}{l}\text { North Sea } \\
\text { (winter) }\end{array}$ & $1976-2013$ & 0.0007 & 38 & 0.001 & 0.846 \\
\hline & SF Bay & $1990-2013$ & 0.0427 & 287 & 0.004 & 0.300 \\
\hline & Bohai Sea & 1960-1999 & 0.0632 & 40 & 0.287 & $<0.001$ \\
\hline \multirow{3}{*}{$\begin{array}{l}\text { Discharge } \\
\left(\mathrm{km}^{3} \mathrm{yr}^{-1}\right)\end{array}$} & Changjiang & $1970-2002$ & 3.34 & 33 & 0.068 & 0.142 \\
\hline & Huanghe & 1960-2009 & -0.750 & 40 & 0.251 & $<0.001$ \\
\hline & North Sea & $1977-2010$ & -7.43 & 34 & 0.103 & 0.064 \\
\hline \multirow{2}{*}{$\begin{array}{l}\text { DIN load } \\
\left(\mathrm{kt} \mathrm{yr}^{-1}\right)\end{array}$} & Changjiang & $1970-2002$ & 0.0261 & 33 & 0.671 & $<0.001$ \\
\hline & North Sea & $1977-2010$ & -0.0121 & 31 & 0.601 & $<0.001$ \\
\hline $\begin{array}{l}\text { DIP load } \\
\left(\mathrm{Kt} \mathrm{yr}^{-1}\right)\end{array}$ & North Sea & $1981-2010$ & -2.28 & 30 & 0.596 & $<0.001$ \\
\hline \multirow[t]{3}{*}{$\mathrm{Chl}\left(\mathrm{mg} \mathrm{m}^{-3}\right)$} & CARIACO Sta & $1995-2013$ & -0.0462 & 201 & 0.039 & 0.005 \\
\hline & East China Sea & $1997-2010$ & 0.0135 & 152 & 0.021 & 0.073 \\
\hline & SF Bay & $1990-2013$ & 0.131 & 279 & 0.151 & $<0.001$ \\
\hline \multirow{3}{*}{ O2 satu. (\%) } & CARIACO Sta & $1995-2013$ & -0.105 & 180 & 0.009 & 0.198 \\
\hline & East China Sea & 1981-2006 & -0.536 & 9 & 0.390 & 0.072 \\
\hline & SF Bay bottom & $1993-2013$ & -0.290 & 251 & 0.042 & 0.001 \\
\hline
\end{tabular}

